\title{
Assessment of the Water Chemical Quality Improvement based on Human Health Risk Indexes: application to in Drinking Water Treatment Plants incorporating membrane technologies
}

Ramón López-Roldán ${ }^{\mathrm{a}}$, Alicia Rubalcaba ${ }^{\mathrm{b}}$, Jordi Martin ${ }^{\mathrm{c}}$, Susana González ${ }^{\mathrm{a}}$, Vicenç Martíb,c $^{\text {, }}$ Jose Luis Cortina ${ }^{\mathrm{a}, \mathrm{d}}$

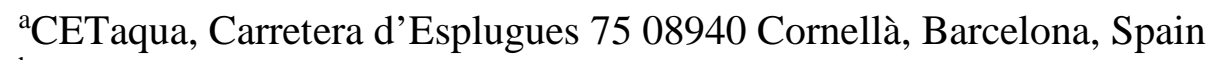

${ }^{\mathrm{b} C T M}$ Technological Centre Foundation, Plaça de la Ciència, No. 2, 08243 Manresa, Spain

cAigües de Barcelona, C/Gral. Batet, 1-7 E-08028 Barcelona, Spain

${ }^{\mathrm{d} D e p a r t m e n t}$ of Chemical Engineering, Universitat Politècnica de Catalunya (UPC), Diagonal 647, 08028 Barcelona, Spain

14

*Corresponding Author: Ramon López-Roldán rlopez@aqualogy.net Phone: +(34) 933124800 / Fax:+ (34) 933124801

\section{ABSTRACT}

A methodology has been developed in order to evaluate the potential risk of drinking water for the health of the consumers. The methodology used for the assessment considers systemic and carcinogenic effects caused by oral ingestion of water based on the reference data developed by the World Health Organization (WHO) and the Risk Assessment Information System (RAIS) for chemical contaminants. The exposure includes a hypothetical dose received by drinking this water according to the analysed contaminants. The assessment of the chemical quality improvement of produced water in the Drinking Water Treatment Plant (DWTP) after integration of membrane technologies using human health risk indexes has been performed.

Series of concentration values covering up to 261 chemical parameters during 5 years (2008-2012) of raw and treated water in the Sant Joan Despi DWTP, at the low part of the Llobregat River basin (NE Spain), have been used. After the application of the methodology, resulting global indexes are located below the thresholds except for carcinogenic risk in the output of DWTP, where the index is slightly above the threshold during 2008 and 2009 before the upgrade of the treatment works with membrane technologies was executed. Annual evolution of global indexes shows a decrease on the global values for all situations: $\mathrm{H}_{\mathrm{Q}}$ systemic index based on RAIS descends from 0.64 to 0.42 for surface water and from 0.61 to 0.31 for drinking water; $\mathrm{R}$ carcinogenic index based on RAIS is negligible for input water and varies from $4.2 \times 10^{-05}$ to $7.4 \times 10^{-06}$ for drinking water; $\mathrm{W}$ systemic index based on WHO moves from 0.41 to 0.16 for surface water and from 0.61 to 0.31 for drinking water. A specific analysis for the indexes associated to trihalomethanes (THMs) shows the same pattern. Those indexes have been presented as a tool to show the improvement of the produced water, especially after the year 2009 where the ultrafiltration (UF) and reverse osmosis (RO) membrane technologies where installed.

\section{KEYWORDS}

Human health risk assessment; Global risk indexes; Membrane technologies; Llobregat River; Trihalomethanes 


\section{HIGHLIGHTS}

- Indexes based on health risk assessment for the treatment of surface water (Llobregat river) to drinking water have been designed

- Annual evolution of indexes shows a decrease on the global index for all situations

- An upgrade in the water treatment is specially remarkable to improve the carcinogenic risk index for drinking water

\section{INTRODUCTION}

In developed countries, a wide implementation of water treating technologies and a proper management has led to a remarkable reduction of the risks associated to water ingestion. Good practices have led to a decrease of the pollution in origin and to a better removal of the contaminants. In the European Union (EU) the Drinking Water Directive (98/83/EC) concerns the quality of water intended for human consumption. According to this legislation, a total of 48 microbiological, chemical and indicator parameters must be monitored and tested regularly. Nevertheless, the list of contaminants that should be taken into account is continuously growing as the studies to define the effects on health are progressing.

Water safety plans are considered by the World Health Organization (WHO) as the most effective means of maintaining a safe supply of drinking water to the public. Hazards and risks should be identified, and appropriate steps towards minimizing these risks are then investigated (WHO, 2005). Additionally, the incidence of global driving forces, including climate change, increasing water scarcity, population growth, demographic changes and urbanization are expected to affect the resilience of water supply and sanitation systems and services, forcing also managers to adapt their infrastructures to these driving forces (Guha-Sapir et al., 2011).

Membrane technologies have been identified as the most robust and flexible technologies used to improve water quality and taste by removing undesirable compounds and pathogens (Rahardianto et al., 2007; Reverberi and Gorenflo, 2007). Reverse osmosis (RO), nanofiltration (NF) and reverse electrodialysis (RED) are being applied worldwide to meet these needs (Birnhack and Lahav, 2007; Greenlee et al., 2009; Wang et al., 2006). The selection of a suitable membrane technology is based on technical criteria (removal of contaminants) and economic aspects (capital operation and maintenance). Implementation of new technologies in drinking water treatment plants (DWTP), as membrane technologies, improves quality of potable water as remove toxic contaminants and reduces human health risk associated to its consumption.

However, it should be stressed that in order to ensure the minimization of pathogens the required treatment generates disinfection by-products (DBPs), one of the main drawbacks of the drinking water production. Those compounds are produced by the reaction between chemical disinfectants and naturally occurring organic material in the source water (Boorman et al., 1999; Krasner, 2009). The trihalomethanes (THMs), the most abundant DBPs, are human carcinogens according to the WHO (2005). From January $1^{\text {st }} 2009$, a limit of total THMs of $100 \mu \mathrm{gL}^{-1}$ is established in the EU 
100 (98/83/EC). Although values have been established for a number of DBPs, risks 101 associated with an inadequate disinfection are far greater than potential risks from long-

104 It is widely accepted that all stakeholders responsible for water safety should place efforts in improving risk management and risk communication to the consumers, that is, the provision of information and health-based assessments on the various microbial, chemical, radiological and physical human health hazards that may be present in the water cycle. Evaluation of existing and emerging hazards in water should include a proper monitoring at source, after treated and along the distribution network for reducing the risks and a proper approach to manage those associated risks.

Assessing exposure and the health consequences of chemicals in drinking water is challenging: exposures are typically at low concentrations, measurements in water are frequently insufficient, chemicals are present in mixtures, exposure periods are usually long, multiple exposure routes may be involved, and valid biomarkers reflecting the relevant exposure period are scarce. In addition, the magnitude of the relative risks tends to be small (Villanueva et al., 2013). Studies to assess the exposure of contaminants due to drinking water ingestion detected values of arsenic and THMs above the threshold in Turkey (Caylak, 2012) and perfluorooctane sulfonate (PFOS) in Taiwan (Chimeddulam and $\mathrm{Wu}, 2013$ ). Industrial contamination led to high risk indexes due to metals in India (Krishna and Mohan, 2014) and Pakistan (Muhammad et al., 2011). Studies in developed countries are more oriented to emerging compounds but they are limited to the availability of reference data. Risk of adverse health effects of pharmaceuticals appeared to be negligibly low in the Netherlands (Houtman et al., 2014). Schriks (2010) concluded that the majority of the compounds evaluated pose individually no appreciable concern to human health in the Rhine and Meuse Rivers. Ribera (2014) used a combination of Life Cycle Assessment (LCA) and human health risk assessment in order to select the percentage of water in DWTPs that should be nanofiltered. Results show a reduction of one order of magnitude for the carcinogenic risk index when NF produces $100 \%$ of drinking water when is compared to the direct consumption without treatment.

In this work, a methodology to determine the evolution of the chemical hazard of water has been developed. Additionally, an assessment is included on how this risk has been impacted after the implementation of the new treatment processes. The methodology is supported on toxic effects assessment, exposure assessment and risk indexes characterization (Durham and Swenberg, 2013). The exposure assessment in the present work only considers ingestion of drinking water containing pollutants through oral route as unique pathway and two typologies of effects on the human health have been considered: a) systemic toxicity that refers to adverse effects on any organ system following absorption and distribution of a chemical throughout the body; and b) carcinogenic effects.

A set of water quality data registered during five years from the DWTP monitoring program has been used to implement the risk assessment methodology. The results obtained will be used to quantify numerically the improvement of the water quality by the use of risk indexes. This study should contribute to develop new managing practices based, not only on the occurrence, but also on the potential hazard of the chemical contaminants. 


\section{MATERIALS AND METHODS}

\subsection{Case study description: Llobregat River and Sant Joan Despí DWTP}

In recent decades, the drinking water supply network of the Barcelona Metropolitan Area (BMA), $635 \mathrm{~km}^{2}$ and a population of 4.5 million inhabitants, has been primarily based on surface water resources from the Llobregat and Ter Rivers. Those resources are suffering the effects of mining and industrial discharges, as well as a reduction in quantity, decreasing the quality of the raw water. Additionally, due to the Mediterranean climate, the natural water resource availability is periodically lower than the water demand in the area (López-Roldán et al., 2013).

To improve the water quality of the Llobregat River and its tributaries, more than 30 waste water treatment plants (WWTPs) treating a mixture of urban and industrial wastewaters have been set up along the river. The main industries sited along the Llobregat River are tannery, food products, textile, pulp and paper industries, discharging a broad spectrum of organic chemicals into the river. Therefore the river receives effluents from these WWTPs and surface runoff from agricultural areas. The removal of contaminants by WWTPs is not complete; consequently they can enter into environment via sewage effluents and thus become a potential risk to the receiving bodies and in addition, to the production of drinking water (González et al., 2012; Köck-Schulmeyer et al., 2011; Valero and Arbós, 2010).

Sant Joan Despí DWTP treats water from the Llobregat River following the process flow-sheet described in Figure 1. The plant has a maximum treatment capacity of 5.5 $\mathrm{m}^{3} \mathrm{~s}^{-1}$, and provides almost 50\% of the annual drinking water in the BMA. In 2009, an improved treatment line began its operation. The new process uses membrane technology and treats $50 \%$ of the water flow with a pre-treatment via micro-coagulation and ultrafiltration (UF) as protection for the RO step. Water is remineralised before being blended with water from the conventional treatment and sent to the postchlorination stages. This process, the membrane treatment line according to Figure 1, is placed after the sand bed filtration where the flow is split and $50 \%$ is treated with the new process; the remaining $50 \%$ will undergo ozonisation and granular activated carbon (GAC) filtration as before.

\subsection{Chemical data quality collection and management}

The Llobregat River has been object of several studies dealing with the presence of contaminants in surface water and related compartments (e.g. sediments, fishes). In this article only compounds detected in the water matrix are taken into account. Most of these studies focus on the lower and medium part of the river basin, where most of WWTPs, DWTPs and population are located, and therefore, it is the area with higher pressures. Pesticides, surfactants, estrogens, pharmaceuticals and personal care products (PPCPs) and even abuse drugs are the main groups detected in different studies, reporting alterations in species composition, abundance or biomass and endocrine disruption measured by alterations in enzymatic activity or specific protein production (González et al., 2012). Nevertheless, a long list of these compounds is not monitored routinely. The lack of data on their presence and their toxicity makes difficult to include them in risk assessment studies on a large time basis. Table 1 provides a list of the chemical compounds routinely monitored by the Sant Joan Despí DWTP in the year 
2012. The selection of the parameters to be analysed is done because of the legislation requirements, local characteristics, occurrence according to historical data and assessment of the efficiency of treatment technologies, among other causes.

Series of data covering monthly averages of 261 chemical parameters during 5 years (2008-2012) of raw and treated water in Sant Joan Despí DWTP have been used. Not all periodically adapted. Moreover, some compounds are only measured in surface water while other compounds are only measured in drinking water.

\subsection{Fundamentals of the risk assessment methodology}

Chemicals that display environmental and biological persistence, bioaccumulation, toxicity and long range transport have been previously assessed quantitatively by national and international health agencies (Szabo and Loccisano, 2012). Among the databases that offer information on the toxicity of the compounds that can be found in water, two of the most widely used are the Risk Assessment Information System (RAIS) and the WHO guidelines (WHO, 2011).

RAIS uses the Reference Dose (RfD), expressed as an oral dose per kilogram of body weight (given in units of $\mathrm{mgKg}^{-1} \mathrm{day}^{-1}$ ), as an estimate of the lowest daily human exposure that is likely to occur without appreciable risk of deleterious, non-cancerous effects during a lifetime. WHO proposes a very similar reference value called the Tolerable Daily Intake (TDI) as an estimate of the amount of a substance in food or drinking-water, also expressed on a body weight basis that can be ingested daily over a lifetime without appreciable health risk (WHO, 1991). The TDI values take into account both systemic and carcinogenic effects but risk index is calculated as systemic.

The exposure assessment of this work only considers ingestion of drinking water containing pollutants through oral route as unique pathway. The oral dose for each contaminant present in water have been calculated by eq 1 :

$D_{i}=\frac{C_{W} \times E F \times E D \times I R_{W}}{B W \times A T \times 365_{\text {days } / \text { year }}}($ eq 1$)$

where Di represents the dose of contaminant by water ingestion ( $\left.\mathrm{mg} \mathrm{Kg}^{-1} \mathrm{day}^{-1}\right), \mathrm{C}_{\mathrm{w}}$ is the annual average concentration of the contaminant in water annual average $\left(\mathrm{mgL}^{-1}\right)$, $\mathrm{EF}$ is the exposure frequency to the contaminated media (days year ${ }^{-1}$ ), ED is the exposure duration (year), $\mathrm{IR}_{\mathrm{w}}$ is the rate of water intake $\left(\mathrm{L} \mathrm{day}^{-1}\right), \mathrm{BW}$ is the body weight of the receptor (Kg), and AT is the average time (year).

Table 2 shows the exposure values for the pathway of oral ingestion of water according to RAIS and WHO for the calculation of doses. For systemic risk $\mathrm{D}_{\mathrm{i}}$ is calculated by using AT=ED. Then, three different indexes (systemic and carcinogenic for RAIS and an index for WHO) have been calculated:

a) the systemic effect index according to RAIS ( $\left.\mathrm{H}_{\mathrm{Qi}}\right)$ is calculated on the dose basis according to RAIS reference values as a ratio between the dose (D) and the dose reference level (RfD) by eq 2: 
$H_{Q i}=\frac{D_{i}}{R_{f D i}}($ eq 2$)$

250

251

252

253

254

255

256

257

258

259

260

261

262

263

264

265

266

267

268

269

270

271

272

273

274

275

276

277

278

279

280

281

282

283

284

285

286

287

288

289

290

291

292

293

294

295

296

297 where the ratio of the average daily dose to a RfD below 1 implies that adverse effects are very unlikely to occur. The guideline values were calculated separately considering the risk for individual substances, without specific consideration of additivity. Although it may result in risk underestimations, unless there is evidence to the contrary, it is appropriate to assume that the toxic effects of these compounds are additive (Backhaus and Faust, 2012). Thus, a global systemic effect is obtained as contribution of the individual index values by eq 3 :

$H_{Q}=\sum H_{Q i} \quad($ eq 3$)$

If $\mathrm{H}_{\mathrm{Q}}$ is below 1 it implies that adverse effects are very unlikely to occur.

b) The individual carcinogenic effects are only considered in RAIS approach and the individual carcinogenic effect index $\left(\mathrm{R}_{\mathrm{i}}\right)$ is calculated by eq 4 :

$R_{i}=D_{i}^{\prime} \times S F_{i} \quad($ eq 4$)$

where SF is the Slope Factor (Kg day mg-1) that express a linear relationship of $\mathrm{D}_{\mathrm{i}}$ versus the risk $\mathrm{Ri}$ at low doses. Cancer risk is calculated by multiplying the estimated dose or exposure level by the appropriate measure of carcinogenic potency. A guideline value of $10^{-5}$ means one additional cancer case per 100000 of the population ingesting drinking-water containing the substance at the guideline value for 70 years (Cothern et al., 1986). Following the principle of additivity of compounds, the global risk index for all compounds is calculated as an addition of individual risk indexes by eq 5:

$R=\sum R_{i}($ eq 5$)$

c) the individual WHO (W) index is developed by using eq 6 .

$W_{i}=\frac{D_{i}}{T D I_{i}} \quad($ eq 6$)$

And then, the global risk index for all compounds is calculated as an addition of individual risk indexes by eq 7 :

$W=\sum W_{i} \quad($ eq 7$)$

\subsection{Contaminant concentrations data treatment and filtering of raw data}

A tool was created and validated using Microsoft Excel ${ }^{\circledR}$ programme for the calculation of risk indexes according to RAIS and WHO toxicity values and doses (eq 1) for the list of compounds by using eq 2-7. The tool was programmed to determine annual average concentration of the compounds. Values representing the limit of quantitation (LOQ) for each compound were also introduced so the tool was able to discriminate between measured values and values below LOQ. Blank cells are automatically recognised as not measured parameters in the data analysis. 
The scheme in Figure 2 has been followed in order to assess the risk related to the compounds present in water and incorporates filtering steps to obtain reliable risk indexes mentioned previously. When dealing with raw data concentrations in the calculation of indexes, three main issues where identified and, consequently, filtering steps were applied:

a) The lack of existence of oral toxicity data for each contaminant. The methodology is based on risk approach, so the contaminants without toxicity values given by RAIS or WHO were excluded from index calculations. The comparison of measured contaminants with levels present in the Directive 98/83/EC is a first step that could determine the risk when toxicity is not available.

b) Annual average concentrations were calculated with a mixture of values below the LOQ and quantified values. The election of $\mathrm{LOQ} / 2$ is usually applied and solves the uncertainty of a concentration that could be between zero and LOQ but, at the same time, introduces an uncertainty that has to be considered, as could lead to an overestimation of the risk (James et al., 2009). In order to have an idea of this uncertainty for the annual average values, an uncertainty index " $U$ " has been calculated by using eq 8 .

where $\operatorname{Avg}(0)$ is the average concentration when all the values below LOQ are considered as zero and $\operatorname{Avg}(\mathrm{LOQ} / 2)$ is the average concentration when all the values below LOQ are considered as LOQ/2. This $U$ index is 1 if all the values are below LOQ (maximum uncertainty) and 0 if all the values are higher than LOQ (minimum uncertainty). $\mathrm{U}$ index will be useful to evaluate the uncertainty of final global indexes.

c) Goodness of the analytical techniques for the sensitive measurement of risk indexes. It could happen that some analytical techniques are focused on the detection of contaminants just below the legislative values and are not sensitive enough to calculate the contribution of the contaminants to risk assessment when present at very low concentrations. Thus, an important role of the analytical techniques applied to risk indexes calculation would be to provide LOQ values able to quantify small amounts of risk.

In order to decide which analytical techniques are sensitive enough to measure the risk properly, the calculation of the risk indexes by using LOQ levels was performed. Parameters giving values of individual indexes, based on LOQ, below a threshold $(0.02$ for systemic risk according to RAIS, 0.01 for systemic risk according to WHO and $5 \times 10^{-}$ ${ }^{7}$ for carcinogenic risk) will be included in the index. For the excluded parameters, risk assessment should be performed by comparing the annual average concentration with the limits recognised by legislation, as those thresholds have been also calculated on the basis of risk to human health studies.

Some extra calculations have been programmed so aggregate indexes are easily calculated taking into account some variables e.g. compounds measured at the inlet during the five years and compounds measured at the outlet during the five years. The 
automatically updated. The Excel tool has facilitated the index calculations based on a

\section{RESULTS}

\subsection{Analysis of water quality improvement in the DWTP}

Analysis of the annual evolution, from 2008 to 2012, of the average concentrations of the contaminants is collected in Table 3 and Table 4. Only parameters at the inlet and the outlet that have routinely measured during the five years have been included. As it could be seen, the surface water quality of the inlet water works (Table 3) have improved over the years for most of the parameters, except for arsenic, barium, cyanides, chromium, selenium, tetrachloroethene and tungsten. Other compounds like boron, calcium, strontium, magnesium, nitrates and sulphates remain constant.

In the case of the outlet concentrations (Table 4), a reduction of the contaminants levels could be seen for all the compounds except for chlorates and chromium. This reduction can be explained mainly by the introduction of the RO step where at least $50 \%$ of the total waterworks capacity is treated. When the evolution of the DBPs concentrations is analysed, a reduction of $89 \%$ has been achieved for total THMs. It should also be taken into account that the DWTP is applying disinfection by using chlorine up to 2010 and by using chlorine dioxide from 2010, which is the main responsible for the formation of chlorinated DBPs. However, the presence of bromide and iodide acts as precursors for the formation of brominated and iodinated DBPs. Additionally, and due to the use of an ozonisation step, the formation of bromates from bromide occurred. The introduction of the membrane treatment unit has improved the quality and in terms of the reduction of the high salinity (ca. $0.9 \mathrm{~g} \mathrm{TDSL}^{-1}$ ), the DBPs precursors and the DBPs themselves so the total content of THMs below $100 \mu \mathrm{gL}^{-1}$ is easily accomplished from 2009.

The increase on the chlorate content should be attributed to the substitution of the initial chlorination steps of the treatment by using chlorine dioxide instead of chlorine. Chlorate and chlorites are disinfection by products of the use of chlorine dioxide. In the case of chromium (VI) the increase is due to the contribution of a groundwater pollution plume generated by electroplating industries, for more than 30 years, at industrial areas of the Llobregat Delta. The seasonal recharge of this plume onto surface water provides the detected peaks, always below the limits fixed by the regulation $\left(10 \mu \mathrm{gL}^{-1}\right)$.

\subsection{Risk indexes comparison of raw and treated water}

Global indexes for systemic risk according to RAIS and WHO reference values and carcinogenic risk based on RAIS reference data are shown at Table 5. The global risks indexes have been calculated by addition of the individual ones. For the calculation of the global indexes, only the compounds that have been measured during the five years at the surface water (inlet) on one side, and the compounds measured for the five years at the treated water (outlet) on the other side, have been included in order to obtain comparable global indexes.

A list of compounds is not included in the global index due to the filtering steps performed, due to the unavailability of reference data or to the low sensitivity of the analytical technique. In case they are excluded, annual average concentrations are 

sodium (2008) show levels above Directive reference values.

Figure 3 shows the annual evolution of the global indexes. Thresholds for the three types of indexes have also been included $\left(\mathrm{H}_{\mathrm{Q}}<1 ; \mathrm{R}<10^{-5} ; \mathrm{W}<1\right)$. It should be highlighted being applied in this methodology to the global risk values. Annual evolution of indexes shows a decrease on the global risk for all situations. The biggest reduction can be seen after the first year, 2008, where a severe drought took place. The low average river flow in 2008 (8.12 $\mathrm{m}^{3} \mathrm{~s}^{-1}$ compared to $12.83 \mathrm{~m}^{3} \mathrm{~s}^{-1}$ in 2009) may be associated to higher average concentrations of pollutants and, therefore, an increase of the risk indexes.

From the methodology developed it is also possible to identify the main contaminants contributing to risk. Lists for the top 10 compounds contributing to every risk index for the year 2012 are shown in Table 9. U indexes shows the uncertainty related to the calculation of the individual risks. The closer $U$ is to 1 , the higher the uncertainty of the value of the annual concentration used for the risk calculation. The compounds posing major risk shows $U$ close to 0 , except for carcinogenic risk at the inlet that is based on compounds not found $(\mathrm{U}=1)$, but global index shows acceptable risk.

For systemic risk according to RAIS reference values, $\mathrm{H}_{\mathrm{Q}}$, the compounds posing a major risk at the inlet are nitrates and nitrites. Nitrates are found at high concentrations and the main risk is linked to their potential of becoming nitrites. Some other compounds like bromates, strontium, boron, barium and nickel are also contributing considerably to the global risk. At the outlet, boron and the halogenated chlorodibromomethane, bromoform, trichloroethene and 1,1,2-trichlorethane appears at the highest position in the list along with the former ones. Some other compounds like the fluorides, free chlorine and metals like thallium, lithium and chromium (VI) and non-metals as arsenic and antimony do not contribute to the global index calculation as the techniques for performing the analysis have been regarded as not sensitive enough. Thus indicates that LOQs should be improved so they can be included in the global risk assessment.

The situation according to the systemic risk index based on WHO values, $\mathrm{W}$, is not so different to the index based on RAIS values, $\mathrm{H}_{\mathrm{Q}}$, regarding the compounds showing the highest contribution to the global index. In this case, the filter has only excluded the pesticide atrazine for the inlet plus free chlorine, chlorates and chlorites in drinking water.

For carcinogenic risk, $\mathrm{R}$, no compounds have a significant risk at the inlet, and values are two order of magnitude below the threshold. Risk is higher at the outlet as DBPs can only be found at the treated water. Compounds like bromates, chromium and arsenic are discarded for contributing to the risk in a big extent due to their high LOQs but were below the values established at the Directive 98/83/CE. At the outlet, legislated THMs and 1,1,2-Trichloroethane have the maximum contribution to the general added risk. A reduction in the risk is especially remarkable beyond 2009. This improvement is associated to the implementation of the RO treatment step, where it expected a reduction of the concentrations of the DBPs precursors (bromide, iodide and dissolved 
organic matter) and also a reduction of the DBP concentration formed in the 448 chlorination step before coagulation (see Figure 1). This reduction is exemplified at 449 Figure 4 where the evolution of the levels of THMs is shown.

\subsection{Contribution of disinfection by-products on risk indexes}

A special analysis has been done to disinfection by-products at drinking water. The four THM's included in the legislation (bromoform, bromodichloromethane, dibromochloromethane, chloroform) are some of the top-ranking compounds in contributing to the global carcinogenic risk. Figure 4 shows the decrease of risk over time due mainly to a reduction of the concentration of THMs. It should be stated that for the four regulated THMs, $U$ is equal to 0 , showing no uncertainty in the risk calculations as the compounds are always quantified above their LOQs.

This reduction can be explained by two main factors: the upgrade of the treatment line by inclusion of the RO desalination treatment in 2009 and the substitution of chlorine by chlorine dioxide with a weaker oxidation potential, and then, with a lower capacity for formation of DBPs. The introduction of a desalination step treating $50 \%$ of the in-let flow rate is reducing the concentration of the DBPs precursors, both inorganic species as bromide and iodide, and organic species, mainly dissolved organic matter (natural and non natural). The reduction of the DBP concentrations up to four times could only be explained by the combination of both changes on the treatment line.

\subsection{Risk indexes methodology advantages and constraints.}

The main advantage of these calculations is related to the fact that they are based on three accepted approaches on the assessment of health risks, differentiating between systemic and carcinogenic risk. Those indexes are considering all measured parameters even if the monthly average concentrations are below the LOQ. The obtained indexes can be recalculated as long as new substances are analyzed and WHO or RAIS is recognizing new toxicity values.

But as those global indexes integrate individual values of specific pollutants, it is noticeable that final risk values would increase as new parameters are measured, even if the results of the analytics are below the quantification limit. In order to cope with this problem, it is important to establish filters so substances presenting high-risk values when concentrations are below quantification limits do not overestimate global health risks.

Series of data show some limitations when the methodology is applied. Monthly averages are calculated on the base of different frequency of measurements depending on the specific parameter, so the number of analysis and the time where they were performed can have an influence on the results. Additionally, not the same list of parameters has been registered during the 5 years. In order to be able to perform an annual comparison, global indexes only includes the parameters that have been measured during the five years covered in the study.

Analytical techniques have their own constraints as no concentration values can be reported under LOQ. This LOQ is not only dependent on the technique, but on the specific compound, water matrix, and the methodology applied for the analytical 
measurements. Due to some facts like the replacement of the instruments and the criteria for the calculation and acceptance of these limits, an evolution of LOQs can also be observed, making more difficult the interannual comparison.

Another issue to be faced is presented when trying to assess the risk of produced water in comparison with raw water at the inlet of a DWTP. This analysis can be interesting when evaluating the performance of the treatment technologies in removing certain substances. The difficulties arise when some analytes are only measured in one of the water streams as their presence is not expected in the outlet, due to the optimum removal efficiency, or in the inlet, due to their production as result of the treatment of the water flow, e.g. DBPs. The differences in the list of compounds analysed and a change in the limit of quantification, due to the analysis in different water matrixes, pose an additional difficulty in the assessment.

\section{CONCLUSIONS}

A methodology has been developed in order to assess globally the chemical risk of drinking water and its source water. Indexes have been created including those parameters that have passed all the quality filters (existence of reference toxicological values and concentration measured with a sensitive analytical technique). The average concentration of the parameters that were excluded from the hazard indexes has been compared to the threshold established at the legislation.

The annual evolution of the global indexes at the intake and the outlet of a DWTP has reported a continuous decrease of the toxicity from 2008 to 2012. After the application of the methodology, resulting global indexes are located below the thresholds except for carcinogenic risk in the output of the DWTP, where the index is slightly above the threshold during 2008 and 2009 before the upgrade of the treatment works with membrane technologies. Annual evolution of indexes shows a decrease on the global values for all situations: $\mathrm{H}_{\mathrm{Q}}$ systemic index based on RAIS descends from 0.64 to 0.42 for surface water and from 0.61 to 0.31 for drinking water; $\mathrm{R}$ carcinogenic index based on RAIS is negligible for input water and varies from $4.2 \times 10^{-05}$ to $7.4 \times 10^{-06}$ for drinking water; W systemic index based on WHO moves from 0.41 to 0.16 for surface water and from 0.61 to 0.31 for drinking water. A specific analysis for the indexes associated to trihalomethanes (THMs) shows the same pattern.

Form the second group of parameters, not included in the calculation of the indexes, only free chlorine and chlorides at 2008 and 2009, and sodium at 2009 showed average concentrations slightly above the threshold for drinking water.

Although risk indexes have been calculated in order to help the decision of the stakeholders in charge of water treatment works and administrations dealing with health issues, it is important not to forget that legislation (e.g. Directive 98/83/EC in Europe) is the main reference when assessing the compliance of water quality to health standards. Those indexes have been presented as a tool to show the improvement of the produced water, especially after the year 2009 where the UF and RO membrane technologies where installed.

The methodology developed in the form of risk indexes has included more parameters than the existing in the legislation to provide a tool based on risk assessment and not 
only on the concentration of legislated parameters. Those indexes take into account different effects (systemic and carcinogenic) and are based on reference values given by international organizations taken into account oral ingestion doses. Indexes developed provide a quantification of the quality improvement that could be integrated with Life Cycle Assessment (LCA) and Life Cycles Costing (LCC) analysis.

To summarize, the methodology introduced is able to estimate the risk reduction win when a change on the treatment line is introduced and could be used to estimate potential health benefits for such investment.

\section{ACKNOWLEDGEMENTS}

The Spanish Ministry of Economy and Competitiveness supported this work through WATMATIN project (CTM2010-21182). Bruno Buzetti is acknowledged for his contribution in the production of the tool for the risk indexes calculation.

\section{REFERENCES}

98/83/EC. Council Directive 98/83/EC of 3 November 1998 on the quality of water intended for human consumption, L 330/32.

Backhaus, T., Faust, M., 2012. Predictive Environmental Risk Assessment of Chemical Mixtures: A Conceptual Framework. Environ. Sci. Technol. 46, 2564-2573. doi:10.1021/es2034125

Birnhack, L., Lahav, O., 2007. A new post-treatment process for attaining Ca2+, Mg2+, SO42- and alkalinity criteria in desalinated water. Water Res. 41, 3989-3997.

doi:10.1016/j.watres.2007.06.007

Boorman, G.A., Dellarco, V., Dunnick, J.K., Chapin, R.E., Hunter, S., Hauchman, F., Gardner, H., Mike, C., Sills, R.C., 1999. Drinking water disinfection byproducts:

Review and approach to toxicity evaluation. Environ. Health Perspect. 107, 207-217. Caylak, E., 2012. Health Risk Assessment for Trace Metals, Polycyclic Aromatic Hydrocarbons and Trihalomethanes in Drinking Water of Cankiri, Turkey. E-J. Chem. 9, 1976-1991.

Chimeddulam, D., Wu, K.-Y., 2013. River water contaminated with perfluorinated compounds potentially posing the greatest risk to young children. Chemosphere 90, 1617-1624. doi:10.1016/j.chemosphere.2012.08.039

Cothern, C.R., Coniglio, W.A., Marcus, W.L., 1986. Estimating risk to human health. Environ. Sci. Technol. 20, 111-116. doi:10.1021/es00144a001

Durham, S.K., Swenberg, J.A., 2013. Risk Assessment, in: Haschek and Rousseaux's Handbook of Toxicologic Pathology. Elsevier, pp. 989-997.

González, S., López-Roldán, R., Cortina, J.-L., 2012. Presence and biological effects of emerging contaminants in Llobregat River basin: A review. Environ. Pollut. 161, 8392. doi:10.1016/j.envpol.2011.10.002

Greenlee, L.F., Lawler, D.F., Freeman, B.D., Marrot, B., Moulin, P., 2009. Reverse osmosis desalination: Water sources, technology, and today's challenges. Water Res. 43, 2317-2348. doi:10.1016/j.watres.2009.03.010

Guha-Sapir, D., Vos, F., Below, R., Ponserre, S., 2011. Annual Disaster Statistical Review 2010: The Numbers and Trends.

Houtman, C.J., Kroesbergen, J., Lekkerkerker-Teunissen, K., van der Hoek, J.P., 2014. 
Human health risk assessment of the mixture of pharmaceuticals in Dutch drinking

598 water and its sources based on frequent monitoring data. Sci. Total Environ. 496, 54-

599 62. doi:10.1016/j.scitotenv.2014.07.022

600 James, A., Bonnomet, V., Morin, A., Fribourg-Blanc, B., 2009. Implementation of

601 Requirements on Priority Substances within the Context of the Water Framework

602 Directive. Prioritization Process: Monitoring-based Ranking (No. Contract NO.

603 07010401/2008/508122/ADA/D2;). International Office for Water (INERIS).

604 Köck-Schulmeyer, M., Ginebreda, A., Postigo, C., López-Serna, R., Pérez, S., Brix, R.,

605 Llorca, M., Alda, M.L. de, Petrović, M., Munné, A., Tirapu, L., Barceló, D., 2011.

606 Wastewater reuse in Mediterranean semi-arid areas: The impact of discharges of tertiary

607 treated sewage on the load of polar micro pollutants in the Llobregat river (NE Spain).

608 Chemosphere 82, 670-678. doi:10.1016/j.chemosphere.2010.11.005

609 Krasner, S.W., 2009. The formation and control of emerging disinfection by-products of

610 health concern. Philos. Trans. R. Soc. Math. Phys. Eng. Sci. 367, 4077-4095.

611 doi:10.1098/rsta.2009.0108

612 Krishna, A.K., Mohan, K.R., 2014. Risk assessment of heavy metals and their source

613 distribution in waters of a contaminated industrial site. Environ. Sci. Pollut. Res. 21,

614 3653-3669. doi:10.1007/s11356-013-2359-5

615 López-Roldán, R., Jubany, I., Martí, V., González, S., Cortina, J.L., 2013. Ecological

616 screening indicators of stress and risk for the Llobregat river water. J. Hazard. Mater.

617 263, 239-247. doi:10.1016/j.jhazmat.2013.07.008

618 Muhammad, S., Shah, M.T., Khan, S., 2011. Health risk assessment of heavy metals

619 and their source apportionment in drinking water of Kohistan region, northern Pakistan.

620 Microchem. J. 98, 334-343. doi:10.1016/j.microc.2011.03.003

621 Rahardianto, A., Gao, J., Gabelich, C.J., Williams, M.D., Cohen, Y., 2007. High

622 recovery membrane desalting of low-salinity brackish water: Integration of accelerated

623 precipitation softening with membrane RO. J. Membr. Sci. 289, 123-137.

624 doi:10.1016/j.memsci.2006.11.043

625 RAIS. The Risk Assessment Information System (RAIS) [WWW Document]. URL

626 http://rais.ornl.gov/index.shtml (accessed 1.31.14).

627 Reverberi, F., Gorenflo, A., 2007. Three year operational experience of a spiral-wound

628 SWRO system with a high fouling potential feed water. Desalination 203, 100-106.

629 doi:10.1016/j.desal.2006.05.005

630 Ribera, G., Clarens, F., Martínez-Lladó, X., Jubany, I., V.Martí, Rovira, M., 2014. Life

631 cycle and human health risk assessments as tools for decision making in the design and

632 implementation of nanofiltration in drinking water treatment plants. Sci. Total Environ.

633 466-467, 377-386. doi:10.1016/j.scitotenv.2013.06.085

634 Schriks, M., Heringa, M.B., van der Kooi, M.M.E., de Voogt, P., van Wezel, A.P.,

635 2010. Toxicological relevance of emerging contaminants for drinking water quality.

636 Water Res. 44, 461-476. doi:10.1016/j.watres.2009.08.023

637 Szabo, D.T., Loccisano, A.E., 2012. POPs and Human Health Risk Assessment, in:

638 Schecter, A. (Ed.), Dioxins and Health. John Wiley \& Sons, Inc., Hoboken, NJ, USA,

639 pp. 579-618.

640 Valero, F., Arbós, R., 2010. Desalination of brackish river water using Electrodialysis

641 Reversal (EDR). Desalination 253, 170-174. doi:10.1016/j.desal.2009.11.011

642 Villanueva, C.M., Kogevinas, M., Cordier, S., Templeton, M.R., Vermeulen, R.,

643 Nuckols, J.R., Nieuwenhuijsen, M.J., Levallois, P., 2013. Assessing Exposure and

644 Health Consequences of Chemicals in Drinking Water: Current State of Knowledge and

645 Research Needs. Environ. Health Perspect. doi:10.1289/ehp.1206229

646 Wang, D.-X., Wang, X.-L., Tomi, Y., Ando, M., Shintani, T., 2006. Modeling the 
647 separation performance of nanofiltration membranes for the mixed salts solution. J.

648 Membr. Sci. 280, 734-743. doi:10.1016/j.memsci.2006.02.032

649 WHO, 1991. Evaluation of certain veterinary drug residues in food: thirty-eighth report 650 of the Joint FAO/WHO Expert Committee on Food Additives.

651 WHO, 2005. Water safety plans: Managing drinking-water quality from catchment to 652 consumer.

653 WHO, 2011. WHO Guidelines for drinking-water quality; 4th ed. Geneva, Switzerland, 654 World Health Organization.

655 WHO, 2014. Water Safety in Distribution Systems.

656

657 
658 Table 1. Chemical parameters routinely monitored at the Sant Joan Despí DWTP (surface 659 water and produced drinking water) in 2012

\begin{tabular}{|c|c|c|c|c|c|}
\hline Parameter & $\begin{array}{l}\text { Frequency inlet } \\
\text { measurements }\end{array}$ & $\begin{array}{l}\text { Frequency outlet } \\
\text { measurements }\end{array}$ & Parameter & $\begin{array}{l}\text { Frequency inlet } \\
\text { measurements }\end{array}$ & $\begin{array}{l}\text { Frequency outlet } \\
\text { measurements }\end{array}$ \\
\hline 1,1-dichloroethane & every 2 weeks & every week & Fluorides & every week & every month \\
\hline 1,1-dichloroethene & every year & every week & Free chlorine residual (in situ) & N/A & every hour \\
\hline 1,1,1-trichlorethane & every 2 weeks & every week & Gallium & every day & every day \\
\hline 1,1,1,2-tetrachloroethane & every year & every week & Geosmin & every 2 weeks & every 2 weeks \\
\hline 1,1,2-trichlorethane & every year & every week & Heptachlor & every week & every month \\
\hline 1,1,2,2-tetrachloroethane & every year & every week & Heptachlor epoxide & every week & every month \\
\hline 1,2-dibromoethane & every year & every week & Indene(1,2,3-c,d)pyrene & every week & every month \\
\hline 1,2-dichloroethane & every year & every week & Indium & every day & every day \\
\hline 1,2-dichloropropane & every year & every week & Iron & every day & every 8 hours \\
\hline 2-methylisoborneol & every 2 weeks & every 2 weeks & Lanthanum & every day & every day \\
\hline $4,4^{\prime}-\mathrm{DDD}$ & every week & every month & Lead & every day & every day \\
\hline 4,4'-DDE & every week & every month & Lindane & every week & every month \\
\hline 4,4'-DDT & every week & every month & Lithium & every day & every day \\
\hline Acenaphthene & every week & every month & $m+p-X y l e n e$ & every 2 weeks & every month \\
\hline Acenaphthylene & every week & every month & Magnesium & every day & every day \\
\hline Alachlor & every week & every month & Malathion & every week & every month \\
\hline Aldrin & every week & every month & Manganese & every day & every day \\
\hline alpha-Endosulfan & every week & every month & Mercury & every week & every day \\
\hline alpha-HCH & every week & every month & Methyl parathion & every week & every month \\
\hline Aluminium & every day & every 8 hours & Metolachlor & every week & every month \\
\hline Ametryne & every week & every month & Molinate & every week & every month \\
\hline Ammonium & every 2 hours & every 12 hours & Molybdene & every day & every day \\
\hline Anthracene & every week & every month & Naphthalene & every week & every month \\
\hline Antimony & every day & every day & Nickel & every 4 hours & every day \\
\hline Arsenic & every day & every day & Nitrates & every week & every month \\
\hline Atrazine & every week & every month & Nitrites & every week & every month \\
\hline Barium & every day & every day & Non-ionic tensioactives & every 2 weeks & $\mathrm{N} / \mathrm{A}$ \\
\hline Benzene & every 2 weeks & every month & o-Xylene & every 2 weeks & every month \\
\hline Benzo(a)anthracene & every week & every month & Palladium & every day & every day \\
\hline Benzo(a)pyrene & every week & every month & Parathion & every week & every month \\
\hline Benzo(b)fluorantene & every week & every month & Pendimethalin & every week & every month \\
\hline Benzo(g,h,i)perylene & every week & every month & Phenanthrene & every week & every month \\
\hline Benzo(k)fluorantene & every week & every month & Phenols & every 2 weeks & $\mathrm{N} / \mathrm{A}$ \\
\hline Beryllium & every day & every day & Phosphorus & every day & every day \\
\hline beta-Endosulfan & every week & every month & Pirimicarb & every week & every month \\
\hline Bismuth & every day & every day & Potassium & every day & every day \\
\hline Boron & every day & every day & Prometrine & every week & every month \\
\hline Bromates & every week & every day & Propanil & every week & every month \\
\hline Bromides & every day & every month & Propazine & every week & every month \\
\hline Bromochloroacetonitrile & N/A & every week & Pyrene & every week & every month \\
\hline Bromoform & every year & every day & Rubidium & every day & every day \\
\hline c-1,2-Dichloroethene & every year & every week & Selenium & every day & every day \\
\hline c-1,3-Dichloropropene & every year & every week & Silicon & every day & every day \\
\hline Cadmium & every day & every day & Silver & every day & every day \\
\hline Calcium & every day & every 8 hours & Simazine & every week & every month \\
\hline Cesium & every 2 months & every year & Sodium & every day & every day \\
\hline Chlorates & N/A & every day & Strontium & every day & every day \\
\hline Chlorfenvinphos & every week & every month & Sulfates & every day & every month \\
\hline Chlorides & every day & every day & Sum 4 PAHs Dir. 98/83/CE & every week & every month \\
\hline Chlorites & N/A & every day & Sum THMs Dir. 98/83/CE & every year & every month \\
\hline Chlorodibromomethane & every year & every day & t-1,2-Dichloroethene & every year & every week \\
\hline Chloroform & every year & every day & t-1,3-Dichloropropene & every year & every week \\
\hline Chlorpyrifos & every week & every month & Terbuthylazine & every week & every month \\
\hline Chromium & every day & every day & Terbutryn & every week & every month \\
\hline Chromium (VI) & every 4 hours & every 4 hours & Tetrachloride carbon & every year & every week \\
\hline Chrysene & every week & every month & Tetrachloroethene & every 2 weeks & every week \\
\hline Cobalt & every day & every day & Thallium & every day & every day \\
\hline Copper & every day & every day & Tin & every day & every day \\
\hline Cyanides & every 8 hours & every month & Tiobencarb & every week & every month \\
\hline Diazinon & every week & every month & Titanium & every day & every day \\
\hline Dibenzo(a,h)anthracene & every week & every month & Toluene & every 2 weeks & every month \\
\hline Dibromoacetonitrile & N/A & every week & Total Haloacetonitriles & N/A & every week \\
\hline Dichlobenil & every week & every month & Total Pesticides & every week & every month \\
\hline Dichloroacetonitrile & N/A & every week & Total Trihalomethanes & N/A & every day \\
\hline Dichlorobromomethane & every year & every day & Trichloroacetonitrile & $\mathrm{N} / \mathrm{A}$ & every week \\
\hline Dieldrin & every week & every month & Trichloroethene & every 2 weeks & every week \\
\hline Endrin & every week & every month & Trichloroethene + Tetrach. & every 2 weeks & every week \\
\hline Ethofumesate & every week & every month & Trifluralin & every week & every month \\
\hline Ethylbenzene & every 2 weeks & every month & Tungsten & every day & every day \\
\hline Fenitrothion & every week & every month & Uranium & every 2 months & every year \\
\hline Fluoranthene & every week & every month & Vanadium & every day & every day \\
\hline Fluorene & every week & every month & Zinc & every day & every day \\
\hline
\end{tabular}


662

663

664

Parameters

EF(days year ${ }^{-1}$ )

ED* (years)

IR $\left(\mathrm{L} \mathrm{day}^{-1}\right)$

BW (kg)

$\mathrm{AT}^{\star}$ (years)

*Sistemic risk: $A T=E D$

RAIS WHO

$350 \quad 365$

24

2

$70 \quad 60$

70 
Table 3. Annual average concentrations of the compounds at the inlet and its percentage of reduction in the year 2012 compared to 2008

\begin{tabular}{|c|c|c|c|c|c|c|c|c|c|c|c|c|}
\hline \multirow[b]{2}{*}{ Parameter (inlet) } & \multirow[b]{2}{*}{ Units } & \multicolumn{2}{|l|}{2008} & \multicolumn{2}{|l|}{2009} & \multicolumn{2}{|l|}{2010} & \multicolumn{2}{|l|}{2011} & \multicolumn{2}{|l|}{2012} & \multirow{2}{*}{$\begin{array}{l}\text { 2008/2012 } \\
\text { Reduction* }\end{array}$} \\
\hline & & Avg Conc & $u$ & Avg Conc & $\mathrm{U}$ & Avg Conc & $\mathrm{U}$ & Avg Conc & $\mathrm{U}$ & Avg Conc & $U$ & \\
\hline Aluminium & $\mu \mathrm{g} / \mathrm{l}$ & 110,285 & 0,000 & 108,792 & 0,000 & 76,006 & 0,000 & 70,283 & 0,000 & 65,689 & 0,000 & $40 \%$ \\
\hline Antimony & $\mu \mathrm{g} / \mathrm{l}$ & 1,386 & 0,030 & 0,864 & 0,289 & 0,500 & 1,000 & 0,750 & 1,000 & 0,750 & 1,000 & $100 \%$ \\
\hline Arsenic & $\mu \mathrm{g} / \mathrm{l}$ & 0,838 & 0,298 & 0,816 & 0,358 & 0,927 & 0,225 & 1,024 & 0,488 & 1,851 & 0,068 & $-121 \%$ \\
\hline Barium & $\mu \mathrm{g} / \mathrm{l}$ & 129,628 & 0,000 & 135,570 & 0,000 & 149,878 & 0,000 & 146,448 & 0,000 & 166,529 & 0,000 & $-28 \%$ \\
\hline Boron & $\mu \mathrm{g} / \mathrm{l}$ & 198,792 & 0,000 & 154,549 & 0,000 & 175,617 & 0,000 & 196,130 & 0,000 & 211,309 & 0,000 & $-6 \%$ \\
\hline Bromates & $\mu \mathrm{g} / \mathrm{l}$ & 16,584 & 0,014 & 6,432 & 0,034 & 2,173 & 0,072 & 2,500 & 1,000 & 2,500 & 1,000 & $100 \%$ \\
\hline Bromides & $\mathrm{mg} / \mathrm{l}$ & 0,894 & 0,000 & 0,627 & 0,000 & 0,580 & 0,000 & 0,644 & 0,000 & 0,632 & 0,000 & $29 \%$ \\
\hline Calcium & $\mathrm{mg} / \mathrm{l}$ & 110,442 & 0,000 & 110,509 & 0,000 & 112,958 & 0,000 & 109,647 & 0,000 & 106,272 & 0,000 & $4 \%$ \\
\hline Cyanides & $\mu \mathrm{g} / \mathrm{l}$ & 0,542 & 0,846 & 0,500 & 1,000 & 0,500 & 1,000 & 0,815 & 0,460 & 3,905 & 0,320 & $-621 \%$ \\
\hline Chlorides & $\mathrm{mg} / \mathrm{l}$ & 390,809 & 0,000 & 268,052 & 0,000 & 254,409 & 0,000 & 255,901 & 0,000 & 263,749 & 0,000 & $33 \%$ \\
\hline Chromium & $\mu \mathrm{g} / \mathrm{l}$ & 2,125 & 0,343 & 1,512 & 0,689 & 1,926 & 0,379 & 1,846 & 0,395 & 2,487 & 0,293 & $-17 \%$ \\
\hline Chromium (VI) & $\mu \mathrm{g} / \mathrm{l}$ & 4,067 & 0,461 & 2,924 & 0,712 & 3,374 & 0,556 & 2,712 & 0,845 & 2,723 & 0,842 & $33 \%$ \\
\hline Diazinon & $\mu \mathrm{g} / \mathrm{l}$ & 0,034 & 0,009 & 0,024 & 0,066 & 0,031 & 0,081 & 0,056 & 0,028 & 0,006 & 0,410 & $82 \%$ \\
\hline Strontium & $\mathrm{mg} / \mathrm{l}$ & 1,658 & 0,000 & 1,689 & 0,000 & 1,790 & 0,000 & 1,733 & 0,000 & 1,708 & 0,000 & $-3 \%$ \\
\hline Iron & $\mu \mathrm{g} / \mathrm{l}$ & 61,401 & 0,000 & 55,864 & 0,000 & 57,235 & 0,000 & 47,908 & 0,000 & 50,766 & 0,000 & $17 \%$ \\
\hline Phosphorus & $\mu \mathrm{g} / \mathrm{l}$ & 267,809 & 0,000 & 175,152 & 0,000 & 182,537 & 0,000 & 163,824 & 0,000 & 181,920 & 0,000 & $32 \%$ \\
\hline Gallium & $\mu \mathrm{g} / \mathrm{l}$ & 1,370 & 0,836 & 1,250 & 1,000 & 1,250 & 1,000 & 1,250 & 1,000 & 1,250 & 1,000 & $100 \%$ \\
\hline Geosmin & $\mathrm{ng} / \mathrm{l}$ & 9,492 & 0,077 & 1,250 & 1,000 & 2,500 & 1,000 & 3,727 & 0,610 & 8,250 & 0,253 & $13 \%$ \\
\hline Lithium & $\mu \mathrm{g} / \mathrm{l}$ & 27,402 & 0,000 & 19,406 & 0,000 & 21,095 & 0,000 & 18,575 & 0,000 & 20,731 & 0,000 & $24 \%$ \\
\hline Magnesium & $\mathrm{mg} / \mathrm{l}$ & 33,988 & 0,000 & 32,559 & 0,000 & 32,955 & 0,000 & 33,250 & 0,000 & 32,485 & 0,000 & $4 \%$ \\
\hline Malathion & $\mu \mathrm{g} / \mathrm{l}$ & 0,006 & 0,573 & 0,004 & 1,000 & 0,004 & 1,000 & 0,004 & 1,000 & 0,004 & 1,000 & $100 \%$ \\
\hline Manganese & $\mu \mathrm{g} / \mathrm{l}$ & 54,221 & 0,000 & 32,831 & 0,000 & 27,360 & 0,000 & 24,742 & 0,000 & 26,520 & 0,000 & $51 \%$ \\
\hline Mercury & $\mu \mathrm{g} / \mathrm{l}$ & 0,059 & 0,000 & 0,018 & 0,487 & 0,014 & 0,805 & 0,014 & 0,837 & 0,014 & 0,812 & $76 \%$ \\
\hline Molybdene & $\mu \mathrm{g} / \mathrm{l}$ & 2,100 & 0,020 & 1,457 & 0,029 & 1,521 & 0,000 & 1,383 & 0,000 & 1,400 & 0,030 & $33 \%$ \\
\hline Nickel & $\mu \mathrm{g} / \mathrm{l}$ & 10,669 & 0,000 & 6,888 & 0,000 & 5,083 & 0,000 & 6,189 & 0,000 & 8,924 & 0,000 & $16 \%$ \\
\hline Nitrates & $\mathrm{mg} / \mathrm{l}$ & 9,949 & 0,000 & 9,810 & 0,000 & 11,818 & 0,000 & 10,422 & 0,000 & 9,372 & 0,000 & $6 \%$ \\
\hline Nitrites & $\mathrm{mg} / \mathrm{l}$ & 0,491 & 0,000 & 0,339 & 0,000 & 0,290 & 0,000 & 0,328 & 0,000 & 0,164 & 0,038 & $67 \%$ \\
\hline Potassium & $\mathrm{mg} / \mathrm{l}$ & 37,768 & 0,000 & 26,167 & 0,000 & 24,248 & 0,000 & 26,619 & 0,000 & 29,519 & 0,000 & $22 \%$ \\
\hline Rubidium & $\mu \mathrm{g} / \mathrm{l}$ & 30,274 & 0,017 & 13,611 & 0,230 & 21,171 & 0,049 & 9,978 & 0,365 & 12,261 & 0,127 & $59 \%$ \\
\hline Selenium & $\mu \mathrm{g} / \mathrm{l}$ & 0,799 & 0,365 & 0,611 & 0,682 & 0,500 & 1,000 & 0,818 & 0,840 & 1,029 & 0,486 & $-29 \%$ \\
\hline Silicon & $\mathrm{mg} / \mathrm{l}$ & 1,740 & 0,000 & 1,830 & 0,000 & 2,159 & 0,000 & 1,720 & 0,000 & 1,375 & 0,000 & $21 \%$ \\
\hline Sodium & $\mathrm{mg} / \mathrm{l}$ & 199,810 & 0,000 & 142,642 & 0,000 & 133,269 & 0,000 & 144,095 & 0,000 & 147,260 & 0,000 & $26 \%$ \\
\hline Sulphates & $\mathrm{mg} / \mathrm{l}$ & 170,747 & 0,000 & 167,688 & 0,000 & 176,347 & 0,000 & 170,975 & 0,000 & 164,838 & 0,000 & $3 \%$ \\
\hline Thallium & $\mu \mathrm{g} / \mathrm{l}$ & 1,779 & 0,527 & 1,391 & 0,824 & 1,250 & 1,000 & 1,603 & 0,585 & 1,486 & 0,701 & $16 \%$ \\
\hline Non-ionic tensioactives & $\mathrm{mg} / \mathrm{l}$ & 0,090 & 0,000 & 0,068 & 0,000 & 0,092 & 0,000 & 0,081 & 0,000 & 0,083 & 0,000 & $8 \%$ \\
\hline Terbuthylazine & $\mu \mathrm{g} / \mathrm{l}$ & 0,042 & 0,000 & 0,072 & 0,000 & 0,012 & 0,161 & 0,020 & 0,108 & 0,018 & 0,136 & $56 \%$ \\
\hline Terbutryn & $\mu \mathrm{g} / \mathrm{l}$ & 0,007 & 0,796 & 0,005 & 0,665 & 0,004 & 1,000 & 0,004 & 0,795 & 0,004 & 1,000 & $100 \%$ \\
\hline Tetrachloroethene & $\mu \mathrm{g} / \mathrm{l}$ & 0,138 & 0,264 & 0,260 & 0,022 & 0,125 & 1,000 & 0,145 & 0,788 & 0,156 & 0,735 & $-13 \%$ \\
\hline Titanium & $\mu \mathrm{g} / \mathrm{l}$ & 1,938 & 0,000 & 1,837 & 0,023 & 1,232 & 0,135 & 1,745 & 0,072 & 1,608 & 0,078 & $17 \%$ \\
\hline Total Pesticides & $\mu \mathrm{g} / \mathrm{l}$ & 0,150 & 0,764 & 0,125 & 1,000 & 0,141 & 0,815 & 0,141 & 0,007 & 0,020 & 0,063 & $87 \%$ \\
\hline Vanadium & $\mu \mathrm{g} / \mathrm{l}$ & 2,388 & 0,000 & 1,492 & 0,056 & 1,295 & 0,064 & 1,137 & 0,073 & 1,002 & 0,166 & $58 \%$ \\
\hline Tungsten & $\mu \mathrm{g} / \mathrm{l}$ & 2,241 & 0,232 & 1,495 & 0,697 & 1,368 & 0,838 & 1,837 & 0,397 & 3,332 & 0,031 & $-49 \%$ \\
\hline
\end{tabular}

*Percentage of reduction of the concentration of the parameter comparing 2008 and 2012. 100\% of reduction means that the concentration in 2012 has fallen below LOQ 
Table 4. Annual average concentrations of the compounds at the outlet and its percentage of reduction in the year 2012 compared to 2008

Parameter (outlet)
1,1,1-trichlorethane
1,1,2-trichlorethane
1,2-dichloroethane
Aluminium
Antimony
Silver
Barium
Boron
Bromates
Bromoform
Bromides
Calcium
Free chlorine residual (in situ)
Total chlorine residual (in situ)
Chlorates
Chlorites
Chlorodibromomethane
Chloroform
Chlorides
Cobalt
Chromium
Chromium (VI)
Dibromoacetonitrile
Dichlorobromomethane
Strontium
Ethylbenzene
Iron
Fluorides
Phosphorus
Lithium
m+p-Xylene
Magnesium
Manganese
Mercury
Molybdene
Nickel
Nitrates
Potassium
Rubidium
Selenium
Silicon
Sodium
Sulphates
Thallium
Terbuthylazine
Tetrachlorioethene
Toluene
Total Haloacetonitriles
Total Trihalomethanes
Trichloroethene
Trichloroethene + Tetrachloroethene
Vanadium

\begin{tabular}{|c|c|c|c|c|}
\hline \multirow[b]{2}{*}{ Units } & \multicolumn{2}{|l|}{2008} & \multicolumn{2}{|l|}{2009} \\
\hline & Avg Conc & U & Avg Conc & $u$ \\
\hline$\mu \mathrm{g} / \mathrm{l}$ & 0,200 & 0,042 & 0,025 & 1,000 \\
\hline$\mu \mathrm{g} / \mathrm{l}$ & 3,857 & 0,001 & 0,397 & 0,026 \\
\hline$\mu \mathrm{g} / \mathrm{I}$ & 0,281 & 0,111 & 0,119 & 0,480 \\
\hline$\mu \mathrm{g} / \mathrm{l}$ & 44,761 & 0,000 & 86,387 & 0,000 \\
\hline$\mu \mathrm{g} / \mathrm{l}$ & 0,564 & 0,812 & 0,551 & 0,831 \\
\hline$\mu \mathrm{g} / \mathrm{l}$ & $\begin{array}{r}0,669 \\
\end{array}$ & 0,560 & 0,500 & 1,000 \\
\hline$\mu \mathrm{g} / \mathrm{l}$ & 54,383 & 0,000 & $\begin{array}{r}52,663 \\
\end{array}$ & 0,000 \\
\hline$\mu \mathrm{g} / \mathrm{l}$ & 195,303 & 0,000 & 129,547 & 0,000 \\
\hline$\mu \mathrm{g} / \mathrm{l}$ & $\begin{array}{r}5,745 \\
39647\end{array}$ & 0,011 & 7,893 & 0,000 \\
\hline$\mu \mathrm{g} / \mathrm{l}$ & 39,647 & & 35,545 & 0,000 \\
\hline $\mathrm{mg} / \mathrm{l}$ & 0,136 & 0,123 & 0,216 & 0,029 \\
\hline $\mathrm{mall}$ & 134,535 & 0,000 & 108,935 & 0,000 \\
\hline $\mathrm{mg} / \mathrm{l}$ & $\begin{array}{l}1,006 \\
1,192\end{array}$ & 0,000 & $\begin{array}{l}1,00 / \\
1,183\end{array}$ & $\begin{array}{l}0,000 \\
0,000\end{array}$ \\
\hline$\mu \mathrm{g} / \mathrm{l}$ & 85,201 & 0,039 & 954,511 & 0,001 \\
\hline$\mu \mathrm{q} / \mathrm{l}$ & 13,000 & 0,353 & 13,339 & 0,187 \\
\hline$\mu \mathrm{q} / \mathrm{l}$ & 28.842 & 0,000 & 19,148 & 0000 \\
\hline$\mu \mathrm{q} / \mathrm{l}$ & 9373 & 0.000 & 6.023 & 0.000 \\
\hline $\mathrm{mq} / \mathrm{l}$ & 414,610 & 0,000 & 280842 & 0,000 \\
\hline$\mu \mathrm{q} / \mathrm{l}$ & 0,625 & 0,667 & 0,500 & 1000 \\
\hline$\mu \mathrm{q} / \mathrm{l}$ & 2,171 & 0,384 & 1956 & 0.479 \\
\hline$\mu \mathrm{q} / \mathrm{l}$ & 2500 & 1,000 & 2922 & 0,713 \\
\hline & 0,281 & 0,119 & 0,050 & 1000 \\
\hline & 18,654 & 0,000 & 10,881 & 0,000 \\
\hline $\mathrm{mg} / \mathrm{l}$ & 1,852 & 0,000 & 1,626 & 0,000 \\
\hline$\mu \mathrm{g} / \mathrm{l}$ & 0,038 & 0,000 & 0,045 & 0,000 \\
\hline & 9,205 & 0,000 & 8,831 & \\
\hline $\mathrm{mg} / \mathrm{l}$ & 0,151 & 0,000 & 0,114 & 0,055 \\
\hline$\mu \mathrm{q} / \mathrm{l}$ & 24.928 & 0,017 & 13,242 & 0,063 \\
\hline$\mu \mathrm{g} / \mathrm{l}$ & 28,483 & 0,000 & 17.996 & 0,000 \\
\hline$\mu \mathrm{g} / \mathrm{l}$ & 0,071 & 0,000 & 0,052 & 0,000 \\
\hline $\mathrm{mg} / \mathrm{l}$ & 43,063 & 0,000 & 31,344 & 0,000 \\
\hline$\mu \mathrm{g} / \mathrm{l}$ & 1,920 & 0,000 & 1,176 & 0,142 \\
\hline$\mu \mathrm{g} / \mathrm{l}$ & 0,046 & 0,045 & 0,014 & 0,794 \\
\hline$\mu \mathrm{g} / \mathrm{l}$ & 1,104 & 0,189 & 0,975 & 0,214 \\
\hline$\mu \mathrm{g} / \mathrm{l}$ & 5,108 & 0,000 & 3,263 & 0,000 \\
\hline $\mathrm{mg} / \mathrm{l}$ & 10,755 & 0,001 & 10,313 & 0,000 \\
\hline $\mathrm{mg} / \mathrm{l}$ & 34,802 & 0,000 & 23,162 & 0,000 \\
\hline$\mu \mathrm{g} / \mathrm{l}$ & 18,471 & 0,056 & 9,556 & 0,436 \\
\hline$\mu \mathrm{g} / \mathrm{l}$ & 0,569 & 0,805 & 0,500 & 1,000 \\
\hline $\mathrm{mg} / \mathrm{l}$ & 2,507 & 0,000 & 1,643 & 0,000 \\
\hline $\mathrm{mg} / \mathrm{l}$ & 203,257 & 0,000 & 129,339 & 0,000 \\
\hline $\mathrm{mg} / \mathrm{l}$ & 197,292 & 0,000 & 158,333 & 0,000 \\
\hline$\mu \mathrm{g} / \mathrm{I}$ & 1,446 & 0,793 & 1,406 & 0,815 \\
\hline$\mu \mathrm{g} / \mathrm{I}$ & 0,005 & 0,708 & 0,004 & 1,000 \\
\hline$\mu \mathrm{g} / \mathrm{l}$ & 0,395 & 0,047 & 0,084 & 0,822 \\
\hline$\mu \mathrm{g} / \mathrm{I}$ & 0,063 & & 0,093 & 0,000 \\
\hline$\mu \mathrm{g} / \mathrm{l}$ & 0,414 & & 0,150 & 1,000 \\
\hline$\mu \mathrm{g} / \mathrm{I}$ & 96,449 & 0,000 & 46,296 & 0,000 \\
\hline$\mu \mathrm{g} / \mathrm{I}$ & 0,562 & 0,000 & 0,173 & 0,000 \\
\hline$\mu \mathrm{g} / \mathrm{l}$ & 0,953 & 0,000 & 0,305 & 0,000 \\
\hline$\mu \mathrm{q} / \mathrm{l}$ & 1,067 & 0,234 & 0,835 & 0,349 \\
\hline
\end{tabular}

\begin{tabular}{rc}
2010 & \\
Avg Conc & $U$ \\
\hline 0,025 & 1,000 \\
1,117 & 0,000 \\
0,083 & 0,630 \\
57,931 & 0,000 \\
0,500 & 1,000 \\
0,500 & 1,000 \\
36,219 & 0,000 \\
154,589 & 0,000 \\
7,867 & 0,008 \\
19,724 & 0,000 \\
0,165 & 0,076 \\
97,789 & 0,000 \\
0,837 & 0,000 \\
0,967 & 0,000 \\
1012,222 & 0,000 \\
17,021 & 0,171 \\
6,204 & 0,000 \\
0,483 & 0,000 \\
186,797 & 0,000 \\
0,500 & 1,000 \\
2,631 & 0,277 \\
3,240 & 0,579 \\
0,102 & 0,287 \\
0,797 & 0,000 \\
1,226 & 0,000 \\
0,050 & 1,000 \\
8,999 & 0,000 \\
0,119 & 0,035 \\
10,617 & 0,196 \\
13,654 & 0,000 \\
0,050 & 1,000 \\
24,860 & 0,000 \\
1,061 & 0,118 \\
0,013 & 1,000 \\
0,500 & 1,000 \\
2,527 & 0,000 \\
9,138 & 0,000 \\
16,988 & 0,000 \\
8,933 & 0,525 \\
0,500 & 1,000 \\
1,463 & 0,000 \\
98,539 & 0,000 \\
127,833 & 0,000 \\
1,250 & 1,000 \\
0,004 & 1,000 \\
0,119 & 0,472 \\
0,080 & 0,573 \\
0,243 & 0,360 \\
13,267 & 0,000 \\
0,356 & 0,000 \\
0,301 & 0,249 \\
0,558 & 0,821 \\
&
\end{tabular}

$\begin{array}{rl}2011 & \\ \text { Conc } & U \\ 0,125 & 1,000 \\ 1,939 & 0,000 \\ 0,225 & 1,000 \\ 53,135 & 0,000 \\ 0,750 & 1,000 \\ 0,750 & 1,000 \\ 31,276 & 0,000 \\ 13,, 830 & 0,000 \\ 3,636 & 0,458 \\ 20,063 & 0,000 \\ 0,097 & 0,107 \\ 92,806 & 0,000 \\ 0,828 & 0,000 \\ 0,931 & 0,000 \\ 85,978 & 0,000 \\ 14,978 & 0,111 \\ 4,891 & 0,000 \\ 0,745 & 0,000 \\ 179,581 & 0,000 \\ 0,500 & 1,000 \\ 2,239 & 0,326 \\ 3,623 & 0,403 \\ 0,050 & 1,000 \\ 0,633 & 0,000 \\ 1,098 & 0,000 \\ 0,125 & 1,000 \\ 8,389 & 0,000 \\ 0,127 & 0,016 \\ 11,174 & 0,149 \\ 11,287 & 0,000 \\ 0,250 & 1,000 \\ 2,281 & 0,000 \\ 0,901 & 0,185 \\ 0,013 & 1,000 \\ 0,846 & 0,246 \\ 2,747 & 0,000 \\ 7,700 & 0,000 \\ 17,182 & 0,000 \\ 8,302 & 0,565 \\ 0,876 & 0,713 \\ 1,169 & 0,000 \\ 9,359 & 0,000 \\ 110,333 & 0,000 \\ 1,474 & 0,707 \\ 0,004 & 1,000 \\ 0,125 & 1,000 \\ 0,250 & 1,000 \\ 0,150 & 1,000 \\ 12,766 & 0,000 \\ 0,249 & 0,293 \\ 0,360 & 0,521 \\ 0,586 & 0,711 \\ & 1\end{array}$

$2008 / 2012$

Vanadium

$1,067 \quad 0,234$

$0,558 \quad 0,821$

\begin{tabular}{rcr}
\multicolumn{1}{r}{$\begin{array}{r}r 012 \\
\text { Conc }\end{array}$} & Reduction \\
\hline 0,125 & 1,000 & $100 \%$ \\
2,265 & 0,009 & $41 \%$ \\
0,225 & 1,000 & $100 \%$ \\
34,908 & 0,000 & $22 \%$ \\
0,750 & 1,000 & $100 \%$ \\
0,750 & 1,000 & $100 \%$ \\
31,261 & 0,000 & $43 \%$ \\
147,601 & 0,000 & $24 \%$ \\
4,161 & 0,350 & $28 \%$ \\
16,126 & 0,000 & $59 \%$ \\
0,074 & 0,198 & $46 \%$ \\
90,362 & 0,000 & $33 \%$ \\
0,858 & 0,000 & $15 \%$ \\
0,980 & 0,000 & $18 \%$ \\
82,752 & 0,000 & $-866 \%$ \\
9,026 & 0,231 & $31 \%$ \\
4,277 & 0,000 & $85 \%$ \\
0,619 & 0,000 & $93 \%$ \\
183,703 & 0,000 & $56 \%$ \\
0,500 & 1,000 & $100 \%$ \\
3,921 & 0,027 & $-81 \%$ \\
3,073 & 0,678 & $-23 \%$ \\
0,089 & 0,469 & $68 \%$ \\
0,634 & 0,000 & $97 \%$ \\
1,103 & 0,000 & $40 \%$ \\
0,250 & 1,000 & $100 \%$ \\
8,751 & 0,014 & $5 \%$ \\
0,106 & 0,059 & $29 \%$ \\
13,343 & 0,094 & $46 \%$ \\
12,522 & 0,000 & $56 \%$ \\
0,500 & 1,000 & $100 \%$ \\
23,147 & 0,000 & $46 \%$ \\
0,995 & 0,168 & $48 \%$ \\
0,013 & 1,000 & $100 \%$ \\
0,636 & 0,589 & $42 \%$ \\
3,763 & 0,000 & $26 \%$ \\
7,458 & 0,000 & $31 \%$ \\
19,175 & 0,000 & $45 \%$ \\
7,398 & 0,704 & $60 \%$ \\
0,750 & 1,000 & $100 \%$ \\
1,249 & 0,000 & $50 \%$ \\
106,460 & 0,000 & $48 \%$ \\
109,917 & 0,000 & $44 \%$ \\
1,474 & 0,706 & $-2 \%$ \\
0,004 & 1,000 & $100 \%$ \\
0,213 & 0,342 & $46 \%$ \\
0,250 & 1,000 & $100 \%$ \\
0,188 & 0,733 & $55 \%$ \\
11,044 & 0,000 & $89 \%$ \\
0,163 & 0,638 & $71 \%$ \\
0,317 & 0,658 & $67 \%$ \\
0,500 & 1,000 & $100 \%$ \\
0 &
\end{tabular}

Percentage of reduction of the concentration of the parameter comparing 2008 and 2012. 100\% of reduction means that the concentration in 2012 has fallen below LOQ 
Table 5. Global risk indexes calculation for systemic risk according to RAIS reference values $\left(H_{Q}\right)$ and WHO values $(W)$ and carcinogenic risk $(R)$

\begin{tabular}{ccccccc} 
& \multicolumn{3}{c}{ Inlet } & \multicolumn{3}{c}{ Outlet } \\
\cline { 2 - 7 } & $\mathrm{H}_{\mathrm{Q}}$ & $\mathrm{R}$ & $\mathrm{W}$ & $\mathrm{H}_{\mathrm{Q}}$ & $\mathrm{R}$ & W \\
\hline 2008 & 0,64 & $4,62 \mathrm{E}-07$ & 0,41 & 0,61 & $4,21 \mathrm{E}-05$ & 0,32 \\
2009 & 0,50 & $4,51 \mathrm{E}-07$ & 0,31 & 0,50 & $2,66 \mathrm{E}-05$ & 0,25 \\
2010 & 0,49 & $4,68 \mathrm{E}-07$ & 0,30 & 0,41 & $8,18 \mathrm{E}-06$ & 0,19 \\
2011 & 0,47 & $5,11 \mathrm{E}-07$ & 0,32 & 0,33 & $8,06 \mathrm{E}-06$ & 0,17 \\
2012 & 0,42 & $5,24 \mathrm{E}-07$ & 0,16 & 0,31 & $7,40 \mathrm{E}-06$ & 0,17
\end{tabular}


Table 6. Annual averages of the compounds excluded from the $\mathrm{H}_{\mathrm{Q}}$ calculation when reference values from Directive 98/83/CE exist

\begin{tabular}{lrrrrrr} 
Parametre (excluded from $\mathrm{H}_{\mathrm{Q}}$ ) & Unit & 2008 & 2009 & 2010 & 2011 & 2012 \\
\hline Antimony & $\mu \mathrm{g} / \mathrm{l}$ & 0,564 & 0,551 & 0,500 & 0,750 & 0,750 \\
Arsenic & $\mu \mathrm{g} / \mathrm{l}$ & 0,558 & 0,500 & 0,500 & 0,750 & 0,907 \\
Bromates & $\mu \mathrm{g} / \mathrm{l}$ & - & - & - & 3,636 & 4,161 \\
Free chlorine residual (in situ) & $\mathrm{mg} / \mathrm{l}$ & $1,006^{*}$ & $1,007^{*}$ & 0,837 & 0,828 & 0,858 \\
Chlorides & $\mathrm{mg} / \mathrm{l}$ & $414,610^{*}$ & $280,842^{*}$ & 186,797 & 179,581 & 183,703 \\
Chromium & $\mu \mathrm{g} / \mathrm{l}$ & 2,171 & 1,956 & 2,631 & 2,239 & 3,921 \\
Fluorides & $\mathrm{mg} / \mathrm{l}$ & 0,151 & 0,114 & 0,119 & 0,127 & 0,106 \\
Lindane & $\mu \mathrm{g} / \mathrm{l}$ & 0,006 & 0,004 & 0,004 & 0,004 & 0,004 \\
Pirimicarb & $\mu \mathrm{g} / \mathrm{l}$ & 0,006 & 0,006 & 0,006 & 0,006 & 0,006 \\
Sodium & $\mathrm{mg} / \mathrm{l}$ & $203,257^{*}$ & 129,339 & 98,539 & 99,359 & 106,460 \\
Sulfates & $\mathrm{mg} / \mathrm{l}$ & 197,292 & 158,333 & 127,833 & 110,333 & 109,917 \\
Terbuthylazine & $\mu \mathrm{g} / \mathrm{l}$ & 0,005 & 0,004 & 0,004 & 0,004 & 0,004 \\
Trichloroethene + Tetrachloroethene & $\mu \mathrm{g} / \mathrm{l}$ & 0,953 & 0,305 & 0,301 & 0,360 & 0,317
\end{tabular}

*Average concentrations above the thresholds established at Directive 98/83/EC: free chlorine (1 mg/L), chlorides (250 $\mathrm{mg} / \mathrm{L})$ and sodium $(200 \mathrm{mg} / \mathrm{L})$ 
Table 7. Annual averages of the compounds excluded from the $R$ calculation when reference values from Directive 98/83/CE exist

\begin{tabular}{|c|c|c|c|c|c|c|}
\hline Parametre (excluded from R) & Unit & 2008 & 2009 & 2010 & 2011 & 2012 \\
\hline Aldrin & $\mu \mathrm{g} / \mathrm{l}$ & 0,004 & 0,004 & 0,004 & 0,004 & 0,004 \\
\hline alpha-Endosulfan & $\mu \mathrm{g} / \mathrm{l}$ & 0,006 & 0,004 & 0,004 & 0,004 & 0,005 \\
\hline Aluminium & $\mu \mathrm{g} / \mathrm{l}$ & 44,761 & 86,387 & 57,931 & 53,135 & 34,908 \\
\hline Ammonium & $\mathrm{mg} / \mathrm{l}$ & 0,038 & 0,038 & 0,041 & 0,038 & 0,038 \\
\hline Antimony & $\mu \mathrm{g} / \mathrm{l}$ & 0,564 & 0,551 & 0,500 & 0,750 & 0,750 \\
\hline Arsenic & $\mu \mathrm{g} / \mathrm{l}$ & 0,558 & 0,500 & 0,500 & 0,750 & 0,907 \\
\hline beta-Endosulfan & $\mu \mathrm{g} / \mathrm{l}$ & 0,004 & 0,004 & 0,004 & 0,004 & 0,006 \\
\hline Boron & $\mu \mathrm{g} / \mathrm{l}$ & 195,303 & 129,547 & 154,589 & 137,830 & 147,601 \\
\hline Bromates & $\mu \mathrm{g} / \mathrm{l}$ & 5,745 & 7,893 & 7,867 & 3,636 & 4,161 \\
\hline Free chlorine residual (in situ) & $\mathrm{mg} / \mathrm{l}$ & $1,006^{*}$ & $1,007 *$ & 0,837 & 0,828 & 0,858 \\
\hline Chlorfenvinphos & $\mu \mathrm{g} / \mathrm{l}$ & 0,004 & 0,004 & 0,004 & 0,004 & 0,004 \\
\hline Chlorides & $\mathrm{mg} / \mathrm{l}$ & $414,610^{*}$ & $280,842^{*}$ & 186,797 & 179,581 & 183,703 \\
\hline Chromium & $\mu \mathrm{g} / \mathrm{l}$ & 2,171 & 1,956 & 2,631 & 2,239 & 3,921 \\
\hline Dieldrin & $\mu \mathrm{g} / \mathrm{l}$ & 0,004 & 0,004 & 0,004 & 0,004 & 0,004 \\
\hline Iron & $\mu \mathrm{g} / \mathrm{l}$ & 9,205 & 8,831 & 8,999 & 8,389 & 8,751 \\
\hline Fluorides & $\mathrm{mg} / \mathrm{l}$ & 0,151 & 0,114 & 0,119 & 0,127 & 0,106 \\
\hline Heptachlor & $\mu \mathrm{g} / \mathrm{l}$ & 0,006 & - & - & - & - \\
\hline Heptachlor epoxide & $\mu \mathrm{g} / \mathrm{l}$ & 0,004 & 0,004 & 0,004 & 0,004 & 0,004 \\
\hline Lindane & $\mu \mathrm{g} / \mathrm{l}$ & 0,006 & 0,004 & 0,004 & 0,004 & 0,004 \\
\hline Malathion & $\mu \mathrm{g} / \mathrm{l}$ & 0,004 & 0,004 & 0,004 & 0,004 & 0,004 \\
\hline Manganese & $\mu \mathrm{g} / \mathrm{l}$ & 1,920 & 1,176 & 1,061 & 0,901 & 0,995 \\
\hline Mercury & $\mu \mathrm{g} / \mathrm{l}$ & 0,046 & 0,014 & 0,013 & 0,013 & 0,013 \\
\hline Metolachlor & $\mu \mathrm{g} / \mathrm{l}$ & 0,004 & 0,004 & 0,004 & 0,004 & 0,004 \\
\hline Molinate & $\mu \mathrm{g} / \mathrm{l}$ & 0,004 & 0,004 & 0,004 & 0,004 & 0,004 \\
\hline Nickel & $\mu \mathrm{g} / \mathrm{l}$ & 5,108 & 3,263 & 2,527 & 2,747 & 3,763 \\
\hline Nitrates & $\mathrm{mg} / \mathrm{l}$ & 10,755 & 10,313 & 9,138 & 7,700 & 7,458 \\
\hline Nitrites & $\mathrm{mg} / \mathrm{l}$ & 0,010 & 0,010 & 0,010 & 0,010 & 0,010 \\
\hline Pendimethalin & $\mu \mathrm{g} / \mathrm{l}$ & 0,006 & 0,004 & 0,004 & 0,004 & 0,004 \\
\hline Pirimicarb & $\mu \mathrm{g} / \mathrm{l}$ & 0,006 & 0,006 & 0,006 & 0,006 & 0,006 \\
\hline Propazine & $\mu \mathrm{g} / \mathrm{l}$ & 0,006 & 0,006 & 0,006 & 0,006 & 0,006 \\
\hline Selenium & $\mu \mathrm{g} / \mathrm{l}$ & 0,569 & 0,500 & 0,500 & 0,876 & 0,750 \\
\hline Sodium & $\mathrm{mg} / \mathrm{l}$ & $203,257^{*}$ & 129,339 & 98,539 & 99,359 & 106,460 \\
\hline Sulfates & $\mathrm{mg} / \mathrm{l}$ & 197,292 & 158,333 & 127,833 & 110,333 & 109,917 \\
\hline Terbuthylazine & $\mu \mathrm{g} / \mathrm{l}$ & 0,005 & 0,004 & 0,004 & 0,004 & 0,004 \\
\hline Terbutryn & $\mu \mathrm{g} / \mathrm{l}$ & 0,006 & 0,004 & 0,004 & 0,004 & 0,004 \\
\hline Tiobencarb & $\mu \mathrm{g} / \mathrm{l}$ & 0,006 & 0,004 & 0,004 & 0,004 & 0,004 \\
\hline Trichloroethene + Tetrachloroethene & $\mu \mathrm{g} / \mathrm{l}$ & 0,953 & 0,305 & 0,301 & 0,360 & 0,317 \\
\hline
\end{tabular}

*Average concentrations above the thresholds established at Directive 98/83/EC: free chlorine (1 mg/L), chlorides (250 $\mathrm{mg} / \mathrm{L}$ ) and sodium (200 mg/L) 
Table 8. Annual averages of the compounds excluded from the $W$ calculation when reference values from Directive 98/83/CE exist

\begin{tabular}{|c|c|c|c|c|c|c|}
\hline Parametre (excluded from W) & Unit & 2008 & 2009 & 2010 & 2011 & 2012 \\
\hline 1,2-dichloroethane & $\mu g / l$ & 0,281 & 0,119 & 0,083 & 0,225 & 0,225 \\
\hline Alachlor & $\mu g / l$ & 0,006 & 0,004 & 0,004 & 0,004 & 0,004 \\
\hline alpha-Endosulfan & $\mu \mathrm{g} / \mathrm{l}$ & 0,006 & 0,004 & 0,004 & 0,004 & 0,005 \\
\hline Aluminium & $\mu \mathrm{g} / \mathrm{l}$ & 44,761 & 86,387 & 57,931 & 53,135 & 34,908 \\
\hline Ammonium & $\mathrm{mg} / \mathrm{l}$ & 0,038 & 0,038 & 0,041 & 0,038 & 0,038 \\
\hline Arsenic & $\mu g / l$ & 0,558 & 0,500 & 0,500 & 0,750 & 0,907 \\
\hline Atrazine & $\mu g / l$ & 0,006 & 0,006 & 0,006 & 0,006 & 0,006 \\
\hline Benzene & $\mu g / l$ & 0,023 & 0,035 & 0,050 & 0,125 & 0,125 \\
\hline beta-Endosulfan & $\mu g / l$ & 0,004 & 0,004 & 0,004 & 0,004 & 0,006 \\
\hline Bromates & $\mu \mathrm{g} / \mathrm{l}$ & 5,745 & 7,893 & 7,867 & 3,636 & 4,161 \\
\hline Free chlorine residual (in situ) & $\mathrm{mg} / \mathrm{l}$ & $1,006^{*}$ & $1,007^{\star}$ & 0,837 & 0,828 & 0,858 \\
\hline Chlorfenvinphos & $\mu g / l$ & 0,004 & 0,004 & 0,004 & 0,004 & 0,004 \\
\hline Chlorides & $\mathrm{mg} / \mathrm{l}$ & $414,610^{*}$ & $280,842^{*}$ & 186,797 & 179,581 & 183,703 \\
\hline Chromium & $\mu g / l$ & 2,171 & 1,956 & 2,631 & 2,239 & 3,921 \\
\hline Iron & $\mu g / l$ & 9,205 & 8,831 & 8,999 & 8,389 & 8,751 \\
\hline Fluorides & $\mathrm{mg} / \mathrm{l}$ & 0,151 & 0,114 & 0,119 & 0,127 & 0,106 \\
\hline Heptachlor & $\mu g / l$ & 0,006 & 0,004 & 0,004 & 0,004 & 0,004 \\
\hline Heptachlor epoxide & $\mu g / l$ & 0,004 & 0,004 & 0,004 & 0,004 & 0,004 \\
\hline Malathion & $\mu \mathrm{g} / \mathrm{l}$ & 0,004 & 0,004 & 0,004 & 0,004 & 0,004 \\
\hline Manganese & $\mu \mathrm{g} / \mathrm{l}$ & 1,920 & 1,176 & 1,061 & 0,901 & 0,995 \\
\hline Pirimicarb & $\mu g / l$ & 0,006 & 0,006 & 0,006 & 0,006 & 0,006 \\
\hline Propazine & $\mu \mathrm{g} / \mathrm{l}$ & 0,006 & 0,006 & 0,006 & 0,006 & 0,006 \\
\hline Selenium & $\mu g / l$ & 0,569 & 0,500 & 0,500 & 0,876 & 0,750 \\
\hline Sodium & $\mathrm{mg} / \mathrm{l}$ & $203,257^{*}$ & 129,339 & 98,539 & 99,359 & 106,460 \\
\hline Sulfates & $\mathrm{mg} / \mathrm{l}$ & 197,292 & 158,333 & 127,833 & 110,333 & 109,917 \\
\hline Terbutryn & $\mu g / l$ & 0,006 & 0,004 & 0,004 & 0,004 & 0,004 \\
\hline Tiobencarb & $\mu \mathrm{g} / \mathrm{l}$ & 0,006 & 0,004 & 0,004 & 0,004 & 0,004 \\
\hline Trichloroethene + Tetrachloroethene & $\mu g / l$ & 0,953 & 0,305 & 0,301 & 0,360 & 0,317 \\
\hline
\end{tabular}

*Average concentrations above the thresholds established at Directive 98/83/EC: free chlorine (1 mg/L), chlorides (250 $\mathrm{mg} / \mathrm{L})$ and sodium (200 mg/L) 
Table 9. Lists for the compounds having a higher contribution for every risk index and their associated uncertainty in the year 2012

\begin{tabular}{|c|c|c|c|c|c|c|c|c|c|c|c|c|c|c|c|c|c|}
\hline Parameter & $\begin{array}{l}\mathrm{H}_{\mathrm{Qi}} \\
\text { inlet }\end{array}$ & $\mathrm{u}$ & Parameter & $\begin{array}{l}\mathrm{Ri} \\
\text { inlet }\end{array}$ & $\mathrm{U}$ & Parameter & $\begin{array}{l}\text { Wi } \\
\text { inlet }\end{array}$ & $\mathrm{U}$ & Parameter & $\begin{array}{l}\mathrm{H}_{\mathrm{Qi}} \\
\text { outlet }\end{array}$ & $\mathrm{U}$ & Parameter & $\begin{array}{l}\mathrm{Ri} \\
\text { outlet }\end{array}$ & $\mathrm{U}$ & Parameter & $\begin{array}{l}\text { Wi } \\
\text { outlet }\end{array}$ & $\mathrm{U}$ \\
\hline Nitrates & 0.160 & 0.00 & Heptachlor & $1.59 \mathrm{E}-07$ & 1.00 & Nitrates & 0.084 & 0.00 & Nitrates & 0.128 & 0.00 & Chlorodibromomethane & $3.37 \mathrm{E}-06$ & 0.00 & Nitrates & 0.067 & 0.00 \\
\hline Strontium & 0.078 & 0.00 & Benzo(a)pyrene & $8.57 \mathrm{E}-08$ & 1.00 & Boron & 0.041 & 0.00 & Strontium & 0.050 & 0.00 & 1,1,2-trichlorethane & $1.21 \mathrm{E}-06$ & 0.01 & Bromoform & 0.030 & 0.00 \\
\hline Nitrites & 0.045 & 0.04 & Dibenzo $(a, h)$ anthracene & $8.57 \mathrm{E}-08$ & 1.00 & Nickel & 0.025 & 0.00 & Bromoform & 0.022 & 0.00 & Bromoform & $1.20 \mathrm{E}-06$ & 0.00 & Boron & 0.029 & 0.00 \\
\hline Boron & 0.029 & 0.00 & Benzene & $6.46 \mathrm{E}-08$ & 1.00 & Antimony & 0.004 & 1.00 & Boron & 0.020 & 0.00 & Dichlorobromomethane & $3.70 \mathrm{E}-07$ & 0.00 & Nickel & 0.010 & 0.00 \\
\hline Barium & 0.023 & 0.00 & Trichloroethene & $5.40 \mathrm{E}-08$ & 1.00 & Trichloroethene & 0.003 & 1.00 & 1,1,2-trichlorethane & 0.016 & 0.01 & 1,1,2,2-tetrachloroethane & $2.35 \mathrm{E}-07$ & 1.00 & Chlorodibromomethane & 0.007 & 0.00 \\
\hline Nickel & 0.012 & 0.00 & Ethylbenzene & $2.58 \mathrm{E}-08$ & 1.00 & Aldrin & 0.001 & 1.00 & Trichloroethene & 0.009 & 0.64 & 1,2-dichloroethane & $1.92 \mathrm{E}-07$ & 1.00 & Nitrites & 0.005 & 1.00 \\
\hline Heptachlor epoxide & 0.008 & 1.00 & Atrazine & $1.35 \mathrm{E}-08$ & 1.00 & Dieldrin & 0.001 & 1.00 & Heptachlor epoxide & 0.008 & 1.00 & Chloroform & $1.80 \mathrm{E}-07$ & 0.00 & Antimony & 0.004 & 1.00 \\
\hline Molybdene & 0.008 & 0.03 & Benzo(a)anthracene & 8.57E-09 & 1.00 & Simazine & $<0.001$ & 1.00 & Beryllium & 0.007 & 1.00 & 1,2-dichloropropane & $1.69 \mathrm{E}-07$ & 1.00 & Trichloroethene & 0.004 & 0.64 \\
\hline Beryllium & 0.007 & 1.00 & Benzo(b)fluorantene & 8.57E-09 & 1.00 & Tetrachloroethene & $<0.001$ & 0.74 & Chlorodibromomethane & 0.006 & 0.00 & Heptachlor & $1.59 \mathrm{E}-07$ & 1.00 & Tetrachloride carbon & 0.003 & 1.00 \\
\hline Trichloroethene & 0.007 & 1.00 & Indene(1,2,3-c,d)pyrene & 8.57E-09 & 1.00 & Terbuthylazine & $<0.001$ & 0.14 & Nickel & 0.005 & 0.00 & Tetrachloride carbon & $8.22 \mathrm{E}-08$ & 1.00 & Chloroform & 0.001 & 0.00 \\
\hline
\end{tabular}


Fig 1. Diagram of the DWTPs involved in the study. GAC: Granular Activated Carbon; MF: Micro Filtration; REM: Remineralization; RO: Reverse Osmosis; UF: Ultra Filtration. The box indicates the modification introduced on the treatment line including an step of Reverse osmosis

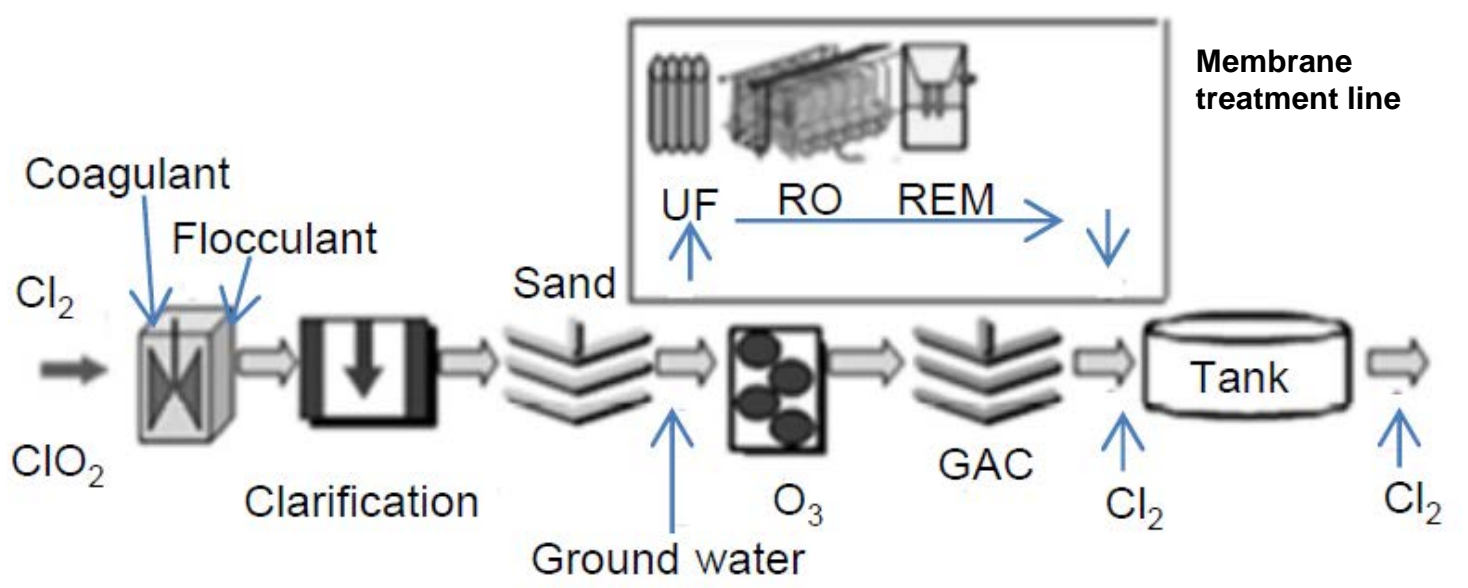


Fig 2. Chart flow representing the methodology for risk assessment and previous filtering steps

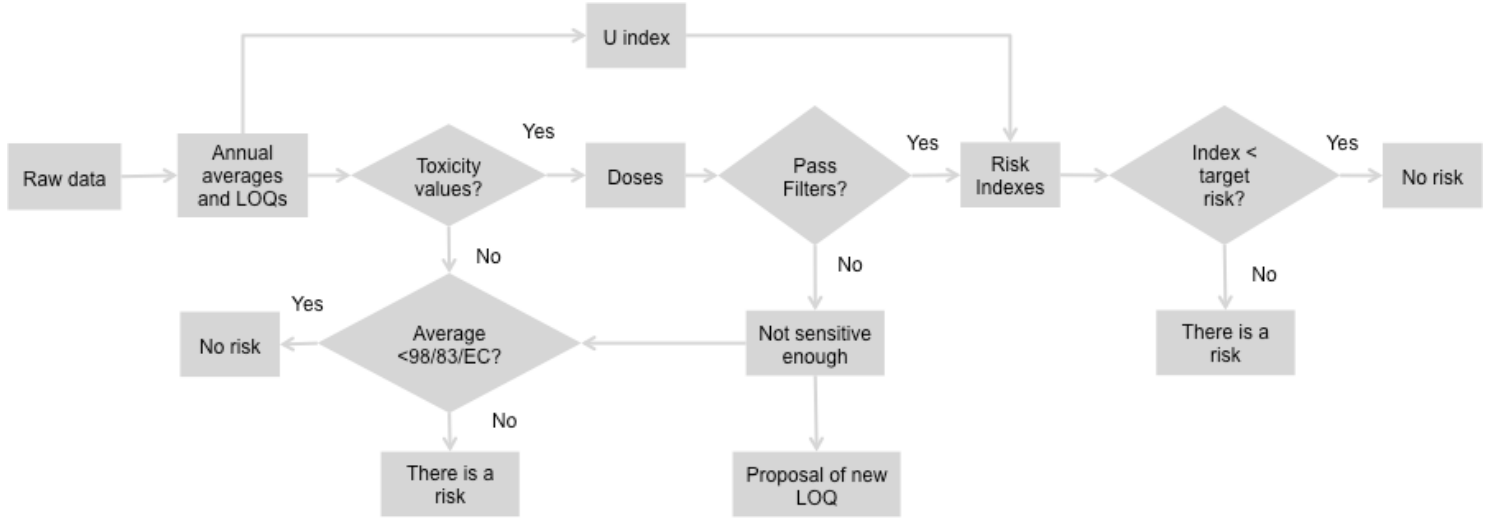


Fig 3. Annual evolution of the global indexes for systemic and carcinogenic risk assessment according to RAIS and WHO reference data
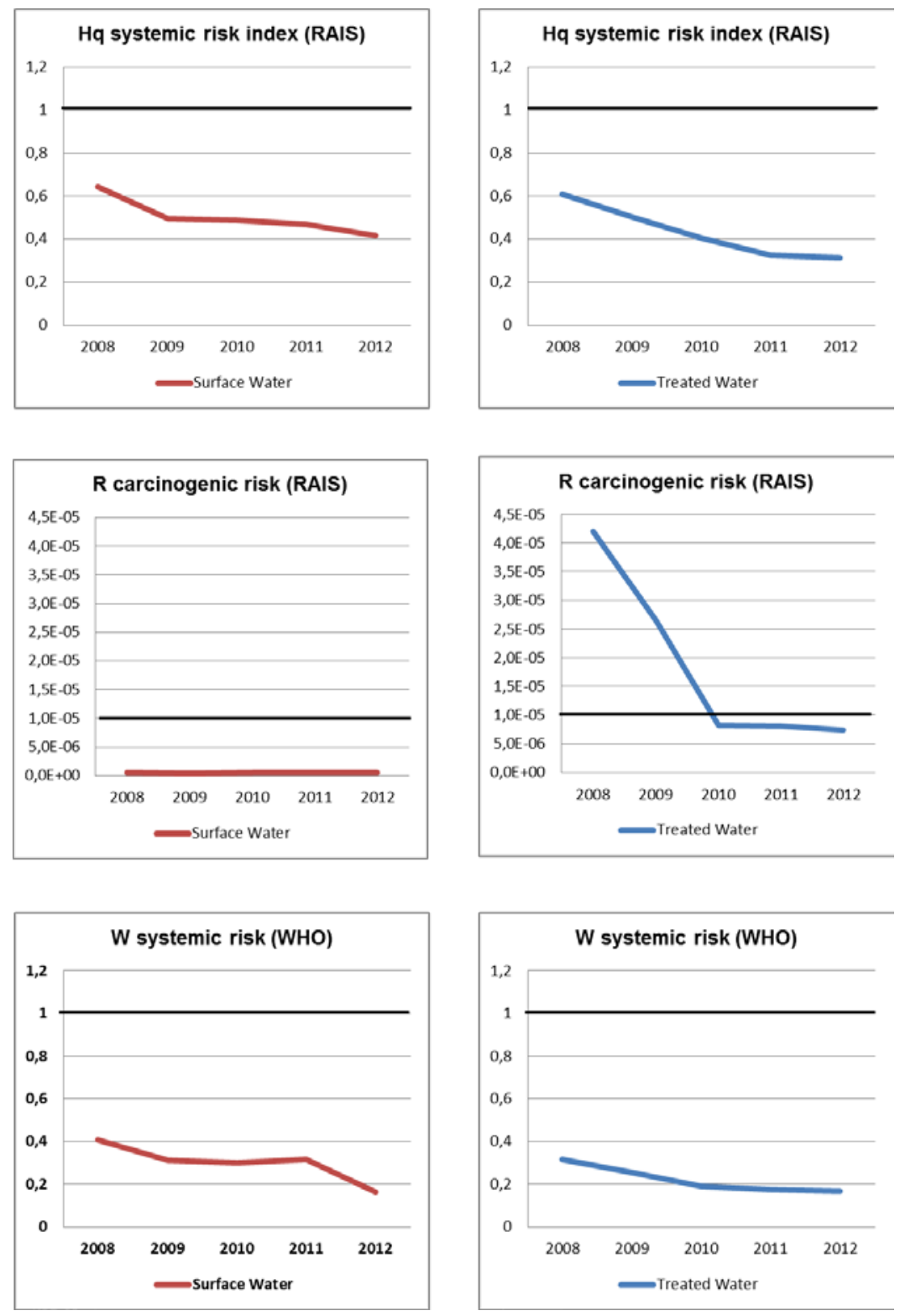
Fig 4. Annual evolution of risk indexes for systemic and carcinogenic risk assessment for the four regulated THMs (bromoform, chlorodibromomethane, chloroform, dichlorobromomethane) at the outlet
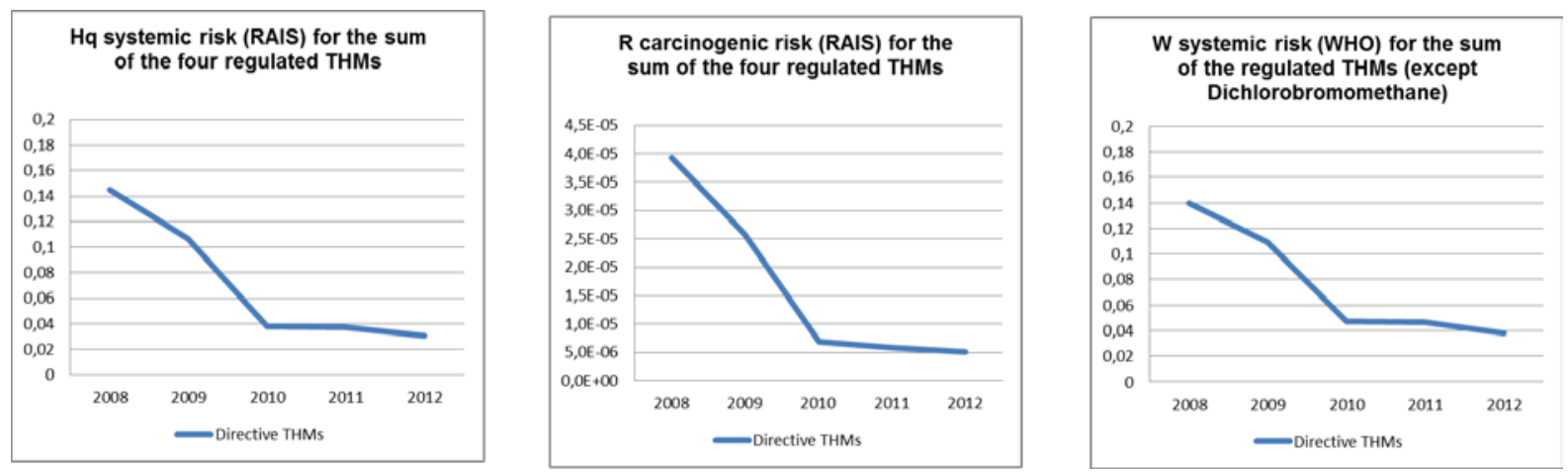